\title{
THE FUNCTIONAL MORPHOLOGY OF OTINA OTIS, A PRIMITIVE MARINE PULMONATE
}

\author{
By J. E. Morton \\ Department of Zoology, Queen Mary College, University of London
}

(Text-figs. I-I2)

The family Otinidae is the smallest and probably the least known among the pulmonates. Thiele (I93I) places it at the base of the Basommatophora, the more primitive order of the subclass Pulmonata, in the Stirps Actophila. It contains a single species, Otina otis Turton, with a geographical range confined to the coasts of the British Isles and north-west France. Its northern distribution reaches as far as the Firth of Clyde, according to Jeffreys (I869), and over the greater part of its British range it appears to follow fairly closely the distribution of the barnacle Chthamalus stellatus, which here reaches its northern limit. Otina otis is a tiny snail, and its external form is limpet-like. The shell, which is well described by Jeffreys (I869), and also by Ellis (I926), measures up to $2.5 \mathrm{~mm}$ in length, with a short apical visceral coil at the posterior end. It is dark chestnut brown in colour, and most resembles a minute Haliotis.

A description of the ecology of Otina otis has already appeared, as portion of a study of the crevice-dwelling animals of the upper intertidal zone at Wembury (Morton, I954). Otina is rather restricted in its mode of occurrence as regards both vertical tidal range and selection of substratum. It lives a short distance within the mouths of crevices between layers of foliaceous rocks, such as Dartmouth Slate at Wembury and Whitsands, and felsite at Kingsands, and in fissures between blocks of Staddon Grit at Rum Bay and volcanic rocks at Drake's Island. Its vertical range at Wembury extends from EHWN tide to the splash zone of MHWN. A favourite site is upon the fringe of Chthamalus stellatus, extending just within a crevice upon a shaded north-facing side, or upon an encrusting layer of the brown alga Ralfsia, with the serpulid Spirorbis borealis somewhat deeper in the crevice. In conditions of high humidity Otina ventures farther out upon the exposed barnacle fringe, where its favourite habit is to hide in the empty shells of Chthamalus, together with specimens of Littorina neritoides, L. rudis and Lasaea rubra. The ecological relation between Otina and Chthamalus would appear to be very close; and the geographical distribution and the distribution of the two species upon the shore to a large extent coincide.

An essentially similar choice of habitat seems to be shown by Otina otis where it occurs on the coast of north-west France. The Inventory of the 
Roscoff Fauna (Station biologique de Roscoff, I95I) records it under stones, in crevices between the rocks, and in empty balanoid shells. It is further stated to shelter in little tufts of algae, as it does sometimes at Plymouth in clumps of the lichen Pygmaea pumila (=Lichina pygmaea), and in the byssus of mussels in the middle to upper tidal zone.

\section{METHODS}

By virtue of its compact shape and small size for sectioning Otina otis is a relatively easy mollusc to study anatomically. During the present investigation animals were dissected alive and after fixation with aqueous Bouin's fluid and with the Dubosq modification of Bouin's. The animals survive for only a short time in the still water of a laboratory vessel and are intolerant of more than a few hours' continued submergence. Living animals were removed from the shell under the higher power of the binocular, and placed in sea water in a cavity slide, where they could be readily dissected with needles, the separate organs of the visceral mass dissociating easily and remaining intact for observation of ciliary and muscular activity in the living state. Dissected preparations were transferred to the monocular for more detailed observation with the $\frac{2}{3}$ objective. Fixation in Bouin's for $24 \mathrm{~h}$ was found sufficient to dissolve the shell entirely, after which it was found advisable to remove with needles the brown-pigmented shell membrane, to assist quick penetration of the clearing and embedding media and the cutting of clean sections. Specimens were examined as cleared transparent objects, both unstained and after staining lightly with Mayer's haemalum, and were embedded for sectioning in paraffin at m.p. $52-56^{\circ} \mathrm{C}$. Transverse and longitudinal sections were cut at 5 and $8 \mu$ thickness. Staining with Heidenhain's azan was found to give ideal histological results, especially for details of the inclusions in the cytoplasm of gland cells and for general nuclear staining. For finer details of ciliary apparatus, recourse was made to iron haematoxylin without counterstaining. Mucicarmine and thionin were each used to detect mucus, and Masson's trichrome, as recommended by Pantin (1946), was found a useful alternative general stain to azan.

\section{EXTERNAL FeATURES}

The animal in life, as it creeps about in moist air, is not completely covered by the shell, which is raised above the substratum to expose the sides of the fleshy foot. These-like the rest of the body-are translucent white in colour; in the crawling animal they are usually kept tumid with blood. The head bears a pair of large rounded lappets, which extend forward to overlap the mouth in front, and almost reach the substratum. Behind them, the buccal mass is rounded and bulbous, appearing pinkish, with a narrow black jaw, visible through the white integument. The cephalic tentacles are short and blunt, springing from the head behind the lappets. They appear flattened and triangular from above, and the eyes are located at the centre of their bases. The sole of the foot is oval in outline. It is divided by a deep transverse groove, which cuts off the semicircular anterior third of the foot from the longer posterior portion. The animal progresses on a firm surface by advancing the front of the foot over the substratum, and fixing it in a forward position while the rest of the foot is brought up behind. The whole sole is ciliated and glandular. The most elaborate gland of the foot, however, is the 
suprapedal gland (Fig. 2, spg) which opens on the upper or anterior surface of the front lobe. The suprapedal gland forms a compact cluster of mucussecreting cells, embedded in the connective tissue of the anterior lobe of the foot. Their contents stain grey-green with Masson's stain, bright pink with mucicarmine. Their ducts interpenetrate between the cells of the overlying columnar epithelium, and a forward ciliary current carries a sheet of secretion to the anterior edge of the foot in the neighbourhood of the mouth. The epithelium overlying the gland is raised in an oval pad of ciliated and gland cells, which may form a cushion or a shallow trough according to the state of contraction of the foot. Farther backwards, towards the base of the foot, the subepithelial gland cells spread upwards to enclose the sides of the epithelial tract, which leads back into a recess, lined with squamous cells. Here a dense cluster of cell ducts thrusts its way to the surface, from the posterior part of the gland, where the cytoplasm differs in being less granular, the secretion staining pale green with Masson's. The whole of the secretion of the suprapedal gland appears to find its way forward to the point of contact of the mouth with the substratum. It plays the chief part in compacting particles of food into a bolus in which they are raked up by the odontophore and drawn into the mouth, with a further secretion of mucus from the buccal glands. Within the gut, the salivary glands are small, and the oesophagus almost non-glandular. The supply of mucus from the foot thus provides the chief binding substance added to the food before it is conveyed to the stomach.

The intrinsic muscles of the foot are arranged in two extensive bands inserted on the shell dorso-laterally, just inside the rim of the aperture. From either side, bundles of fibres radiate downwards into the foot, and spread out to be inserted over the whole width of the sole. They serve, on contraction, to draw the shell close to the ground, and, with the blood contained in the pedal sinus, to bring about the general movements of the foot itself. The suprapedal gland lies anteriorly in a triangular space above the convergence of the two muscle bands. Above the level of the gland, and behind it the foot is crossed by a strong sheet of transverse muscles, which form a long, shallow basin, flooring the haemocoele and containing the viscera above.

The pallial opening (Fig. I, $p o p$ ) is set rather far back on the right side, close to the posterior end of the foot. The anus opens immediately in front of it. The mantle forms a wide skirt, fitting closely over the head and trunk, and reflected as a thin white rim at the edge of the shell. The roof of the mantle cavity is a thin-walled, triangular area, quite transparent and with no special respiratory capillaries. It is longest on the right side, where the kidney (Fig. 2, $k d$ ) lies postero-dorsally to the pallial opening. The kidney is a small, pyramidal sac, with smooth, unfolded lining, its broad base applied behind to the anterior lobe of the digestive gland. The renal pore opens into the pallial cavity just inside the pallial aperture. Farther back, the pallial cavity extends as a wide, shallow recess, lying to the right of the mid-line and not 
shown in Fig. 2. It is overhung by the anterior lobe of the digestive gland, which penetrates into the mantle. The pallial opening, or pneumostome, forms a short, narrow tube lined by a thick sleeve of gland cells (Fig. 4). On the lateral wall, the epithelium is shorter than on the mesial, and is continuous with the pallial skirt below its insertion on the trunk.

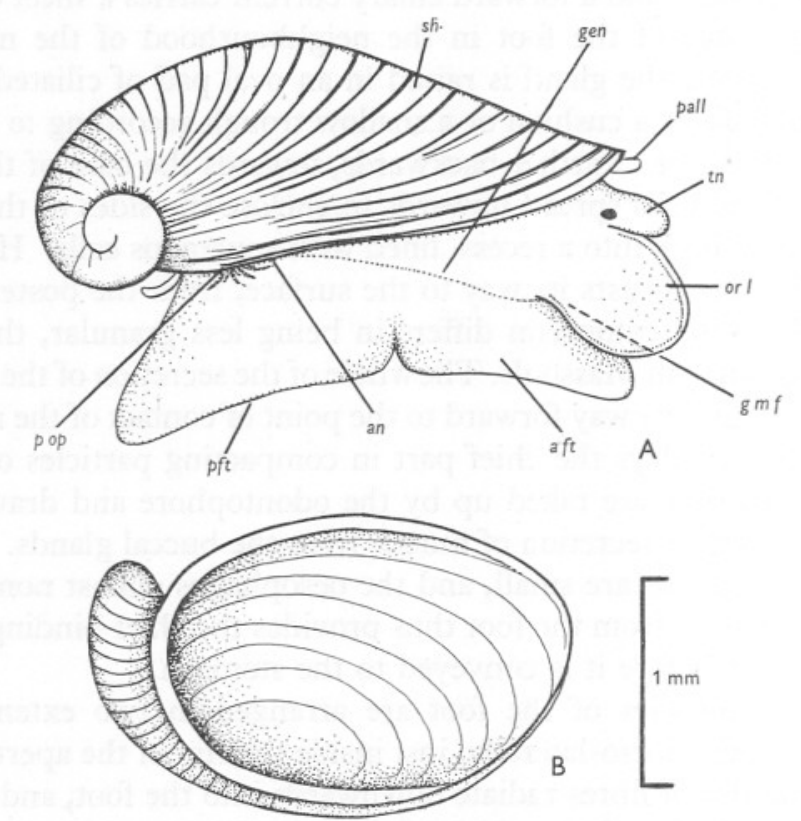

Fig. I. Otina otis. A: lateral view of the entire animal. aft, anterior lobe of the foot; an, position of the anus beneath the pallial skirt; $g m f$, position of the male and female genital apertures beneath the right oral lappet at its posterior edge; gen, course of vagina and vas deferens beneath the integument; or l, oral lappet; pall, projecting margin of the mantle; $p f t$, posterior lobe of the foot; $p o p$, opening of pallial cavity; $s h$, shell; $t n$, cephalic tentacle. B: the shell, viewed from beneath.

The pallial opening in limpet-like gastropods (Graham, personal communication) appears to be always a profusely glandular region. A number of different mucoid secretions are produced, which probably have both a lubricatory and a protective role. In Otina there appear to be three distinct types of subepithelial gland cell (Fig. 4). The first and second types are much the greatest in length (I50 $\mu$ ) and penetrate deeply against the haemocoele on the mesial side. In the first (Fig. $4, g l \mathrm{I}$ ) the cytoplasm forms a coarse reticulum, staining lightly brown in azan; the cell contents are often removed during fixation. The second type of gland $(g l 2)$ stains bright blue in azan. The third type of gland $\left(g l_{3}\right)$ is cylindrical or flask-shaped and is a good deal shorter. The cytoplasm stains various shades of red after azan, towards maturity the cell contents appearing deep wine red to purplish or dark blue. Intermixed 
with these cells, just beneath the surface of the epithelium, are often smaller, rounded cells, uniformly packed with brown staining spherules, and probably representing younger stages of the first type of gland. Towards the pallial cavity the epithelium of the pneumostome flattens to a squamous form and

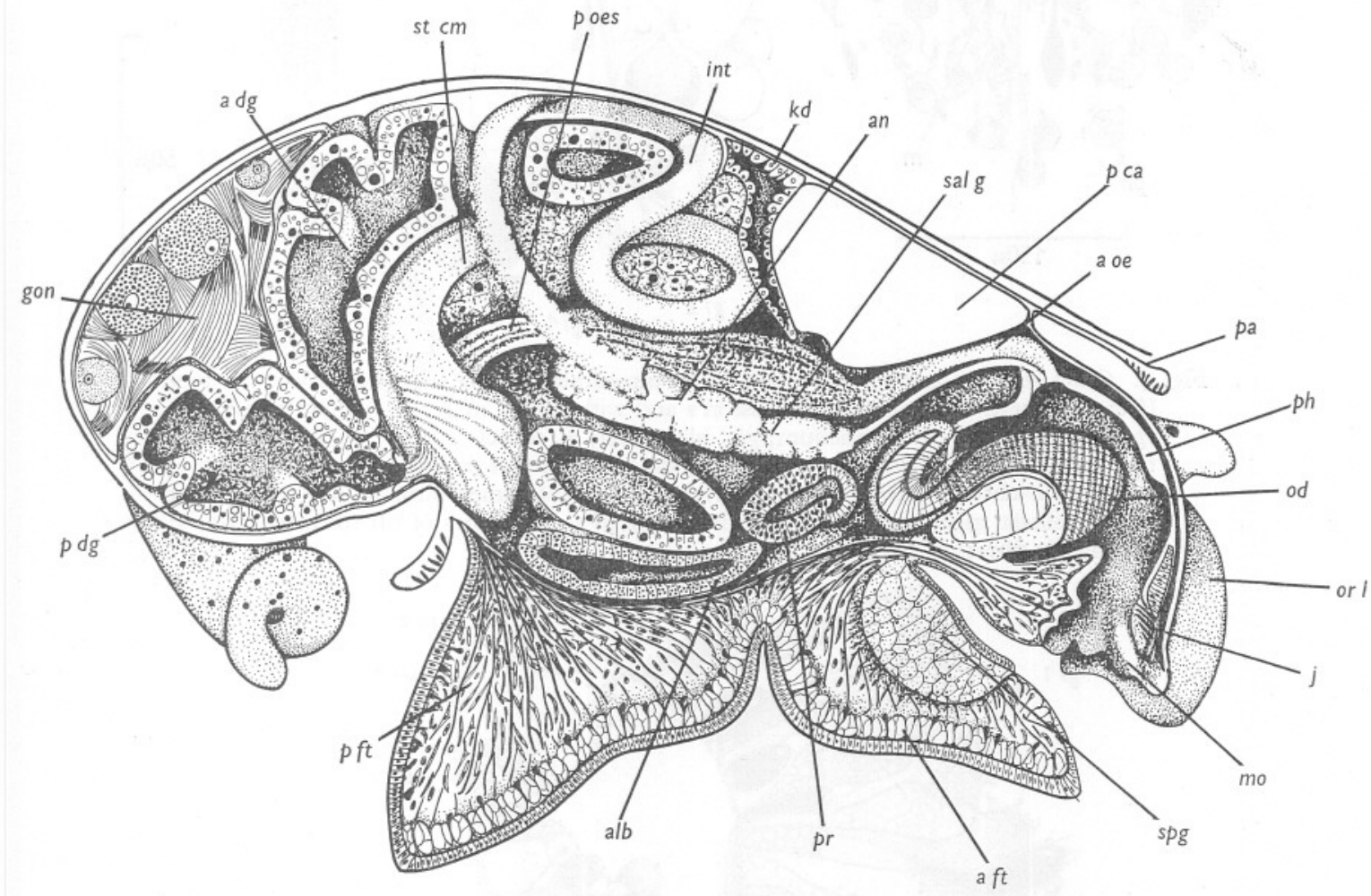

Fig. 2. Otina otis. Semi-diagrammatic longitudinal view of the entire left half of the animal, sectioned along the sagittal plane. The course of the rectum, from the mid-line to the anus, on the right side, has been indicated by broken lines, although actually lying outside the sagittal plane. $a d g$, anterior lobe of the digestive gland; aft, anterior portion of the foot; alb, tubule of the albumen gland; an, position of the anus to right of sagittal plane; $a o e$, anterior region of the oesophagus; gon, ovotestis; int, intestine; $j$, jaw; $k d$, kidney; mo, mouth; od, odontophore; or $l$, oral lappet; $p a$, mantle; $p c a$, pallial cavity; $p d g$, posterior lobe of the digestive gland; $p f t$, posterior division of the foot; $p h$, buccal mass; poes, posterior region of the oesophagus; $p r$, prostate; salg, salivary gland; $s p g$, suprapedal gland; st cm, 'style sac'.

glands of the third type are especially numerous. At the extreme inner edge of the gland mass, there is often a nest of several large-nucleated, spherical cells (Fig. 4, replc), which evidently serve as replacement cells for discharged glands.

The sole of the foot (Fig. 3 B) is lined with columnar epithelium of uniform height ( $15 \mu$ ) with a central row of ovoid nuclei, and a short but dense ciliary 


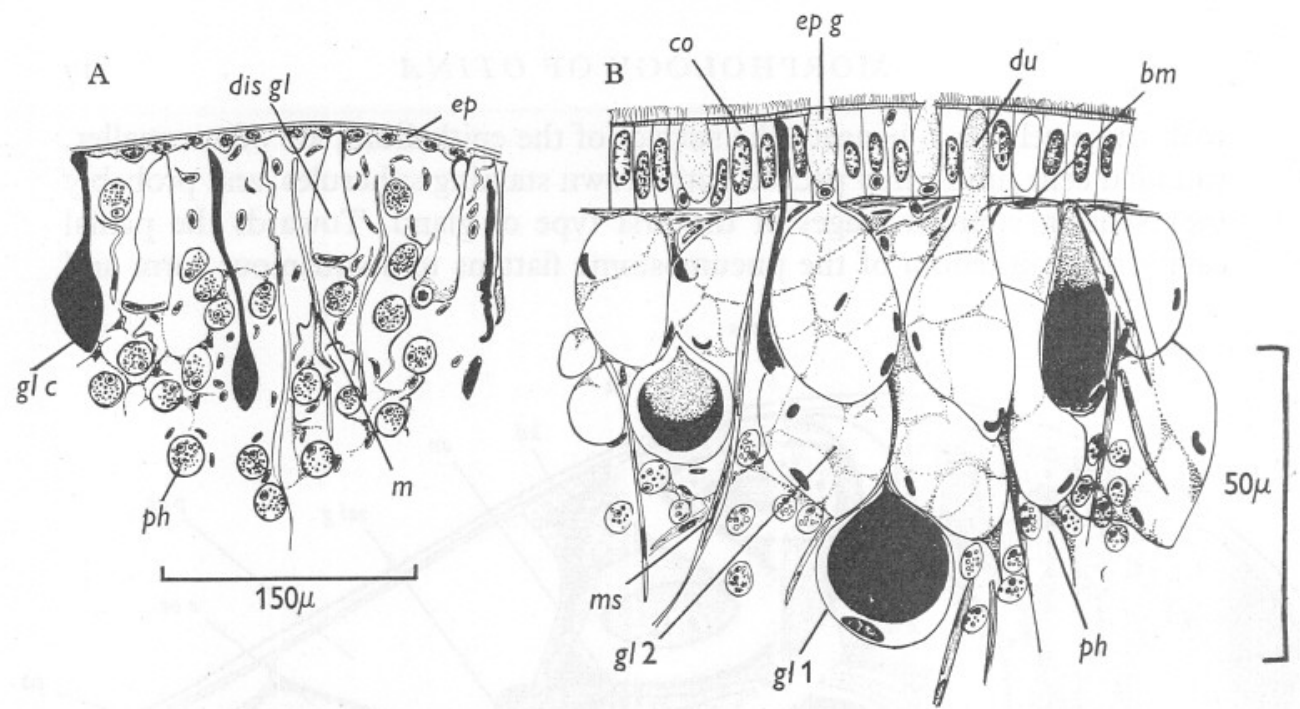

Fig. 3. Otina otis. A: transverse section of the integument in the lateral region of the foot (from preparations stained with Masson's and with azan). disgl, discharged gland cell; $e p$, squamous external epithelium; $g l c$, gland cell; $m$, muscle strand; $p h$, phagocytes in blood sinus. B: transverse section through the epithelium of the sole of the foot (Bouin's; Masson's trichrome). $b m$, basement membrane; co, columnar epithelial cell; $d u$, duct of a subepithelial gland cell; epg, epithelial gland; $g l \mathrm{I}, g l 2$, types of subepithelial glands; $m s$, muscle fibre; $p h$, phagocyte.

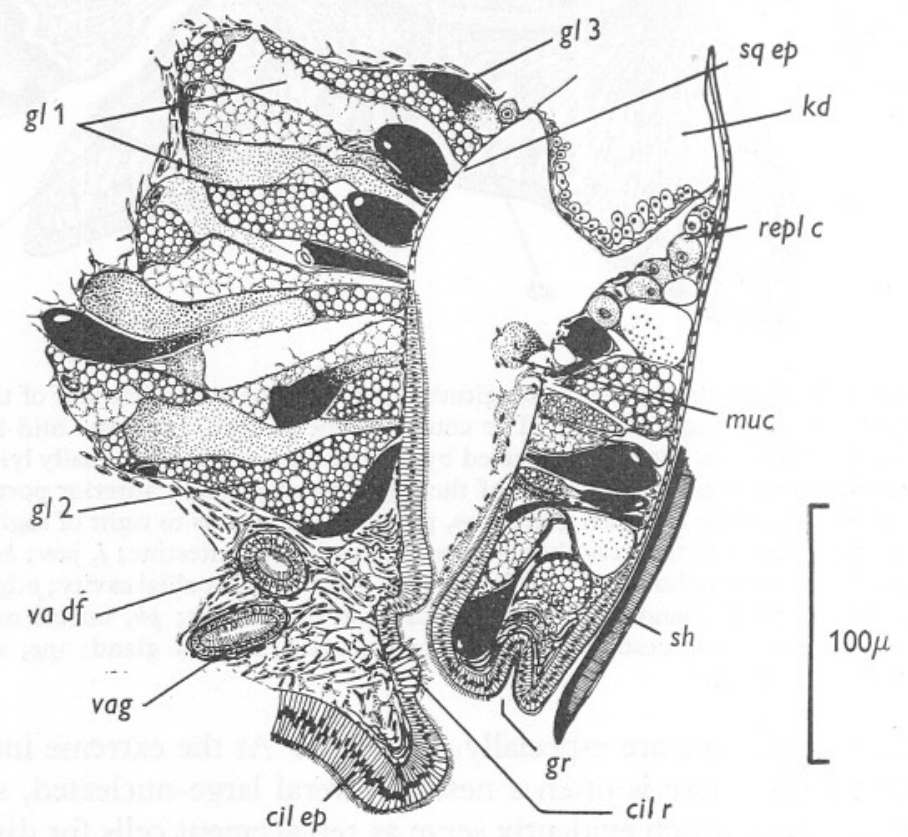

Fig. 4. Otina otis. Transverse section of the pallial cavity near its opening, showing the histology of the epithelium lining the pneumostome (from preparations with Masson's trichrome, and azan). cilep, ciliated columnar epithelium; cilr, ciliated ridge running along the side of the foot below the closure of the mantle cavity; $g l$ I $g l$ 2, $g l$, types of gland cells of the subepithelial layer as referred to in the text; $g r$, secretory groove along the pallial margin; $k d$, kidney; muc, mucus discharged into the pallial cavity; replc, replacement cells; sh, shell; sqep, squamous epithelium; vadf, vas deferens; vag, vagina. 
coat. Between the ciliated cells appear the ducts of large subepithelial glands. Occasionally a whole gland cell, complete with basal nucleus, lies entirely within the columnar layer. Amoebocytes are usually numerous, wandering in from the subepithelial layers. The basement membrane of the epithelium is rather muscular, and incorporates a dense sheet of collagenous connective tissue, to which are attached narrow slips of muscle from the deeper layers of the foot. There are two types of glands, clustered thickly together in supporting connective tissue. The first $(g l 2)$ are ovoid and rounded, much the more numerous and crowded in an almost continuous sheet beneath the basement membrane. They stain bluish in azan, light green after Masson's and in haematoxylin pale purple. Thionin leaves them dark brown. The nuclei are basal or parietal and the ducts are stout and cylindrical, penetrating between the overlying columnar cells. The second type of gland $(g l \mathrm{I})$, much less numerous, stains deeply purple or black in haematoxylin, deep red with azan. It is commonly elongate or fusiform, with a short stout duct running up through the epithelium. Sometimes one or more of these glands becomes depressed beneath the lighter staining cells, and its cell body then appears perfectly spherical with a long dark-staining duct thrusting its way into the epithelium.

The sides of the foot, which in the living animal are exposed to the moist air, are quite different in histology from the sole (Fig. 3 A). Their subepithelial connective tissue forms a large blood sinus, lying on either side laterally to the muscles of the foot, from which it is penetrated by narrow strands of muscle inserted against the epithelium. The external layer is thin and squamous, not ciliated, and with a very narrow refractile border. The basement membrane is rather crenulated by the bulging against it of cell nuclei. Glands are of a single type, staining very darkly in haematoxylin and deep red in azan. These cells form long (100-150 $\mu$ ) vesicles of secretion running deeply into the connective tissue, usually with a flattened nucleus lying horizontally at the cell base. What their function may be is not ascertained. They are probably similar in nature to the dark staining glands $(g l \mathrm{I})$ of the sole, and may have a protective or antiseptic function, similar to that of the multicellular glands described by Fretter (1943, p. 697) in the integument of Onchidella. Within the blood spaces of the sides of the foot, amoebocytes are very numerous $(p h)$, rounded or slightly ovoid after fixing, with a small round, uninucleolate nucleus. They are filled with tiny granular inclusions, staining reddish brown in Masson's, as well as large amorphous clusters of particles. It seems likely that the broad lateral tracts of the foot may in Otina carry on accessory respiratory and excretory activity, especially in view of the reduced size of the pallial cavity, its lack of a respiratory plexus, and the reduction in size of the kidney. At the sides of the foot, blood is brought to the external surface of the body, enclosed only by the thinnest of epithelia through which respiratory interchange might easily be possible with the surrounding air. 
An increase of respiratory surface by epithelial folds is probably unnecessary, in view of the small volume of the animal and its comparative lack of active movements. The amoebocytic cells probably have an excretory role, following on reduction of the kidney and the lack of a pallial water current to carry discharged renal products out of the mantle cavity. A similar occurrence of excretion through the integument by amoebocytic action has been described in several other marine gastropods, for example Omalogyra (Fretter, I948) and the Pyramidellidae (Fretter \& Graham, 1949). Here the laden amoebocytes emerge along a thin strip of epithelium into the pallial cavity. In Osilinus lineatus, Nisbet (personal communication) has observed the excretion of injected particles of carmine by the amoebocytes of the foot.

\section{The Buccal Region}

\section{Alimentary CANAL}

Otina feeds like a limpet by the rasping action of the radula, browsing over the rock surface, and picking up wave-lodged diatoms and detritus. The places where it lives are often not rich in debris; the food tends to be more finely selected than in ellobiids (see Morton, I955a), and the radula is kept constantly at work raking particles into the buccal cavity. The alimentary canal is not much specialized, and presents many features primitive among pulmonates and reminiscent of microphagous prosobranchs. The mouth is a long ventral slit between the oral lappets. The suprapedal mucous gland opens just below it, between the bases of the lappets, and its secretion passes forwards, helping to consolidate a food bolus as the radula works against the substratum. The buccal bulb is relatively large, and occupies the whole of the haemocoele of the convex head. When the animal is extended, the head projects forward from beneath the mantle skirt. The bulb is strongly muscular, especially in front of the odontophore and around the mouth. Its cavity leads dorsally from the mouth; when the muscles forming the oral sphincter are relaxed, the bluntly pointed odontophore is thrust down and the radular ribbon unfolded and licked across the substratum.

Fig. $5 \mathrm{~A}$ shows a schematic view of the buccal bulb, opened from above. In front of and below the tip of the odontophore, the buccal cavity is laterally compressed; it forms a vertical cleft between two smooth, cuticle-covered side walls. The cuticle is penetrated by the ducts of mucous cells clustered beneath the epithelium, and forming on either side a lateral buccal gland, secreting binding mucus as the food is taken in. The secretion is in part released at the level of the substratum, as the radula is actually at work. The buccal glands stain pale blue with azan, red with mucicarmine and black after thionin. Just within the mouth, the anterior wall of the buccal cavity is reinforced by a small crescentic jaw, running across the expanded dorsal channel between the glandular side walls. It serves, when the mouth is opened, to grip on the substratum, providing purchase during the strokes of the radula. It consists 
of a series of close-set, spinulose rods of chitin, embedded in a pad of thickened cuticle. Along the base of the jaw, runs a transverse plate of 'cartilage', consisting of long vacuolated cells, invaded by trabeculae from the surrounding connective tissue.

The odontophore (see Fig. 5 A) is bluntly pointed in front, and covered over its whole free surface by the wide radular membrane, which bears small

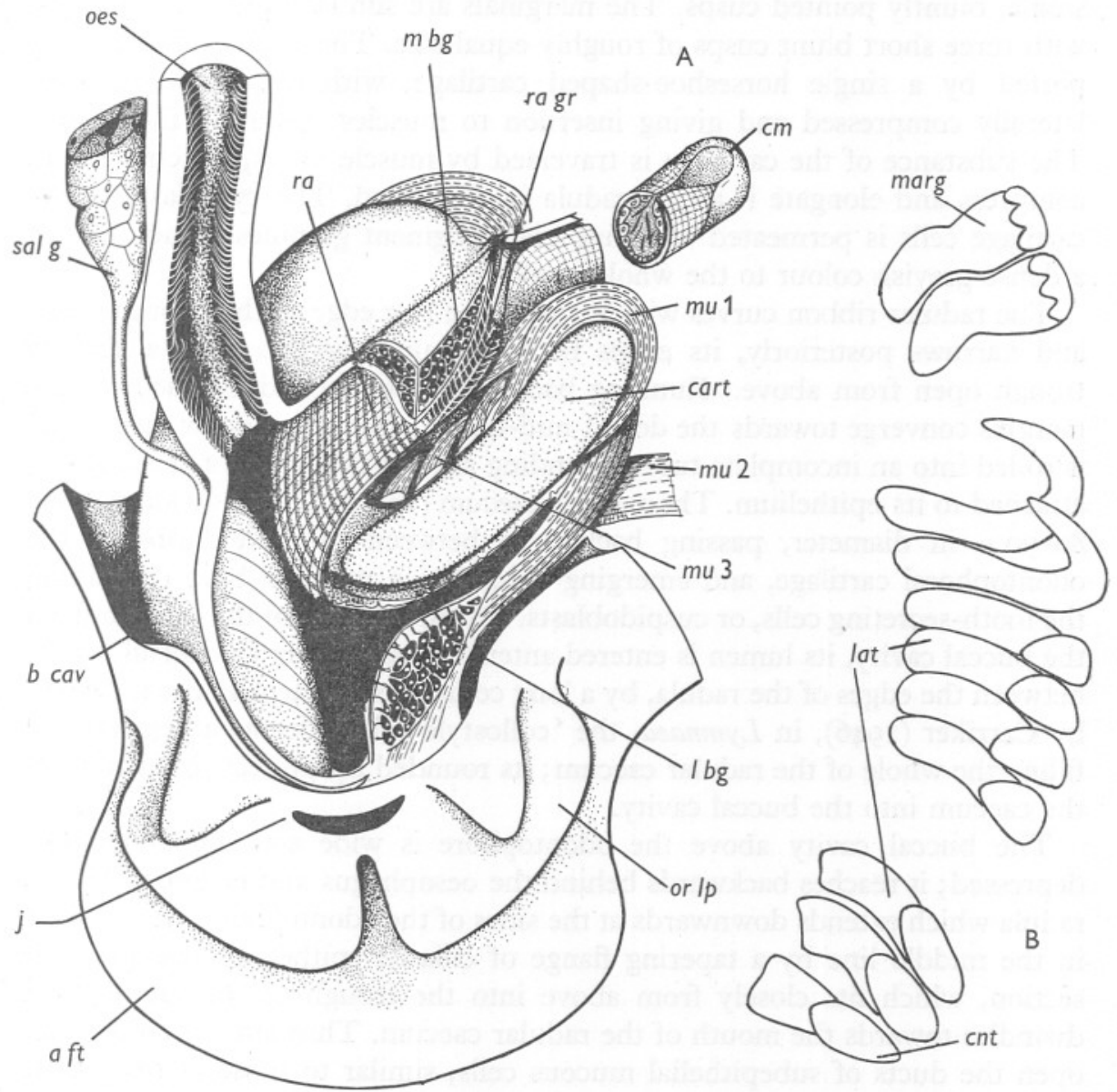

Fig. 5. Otina otis. A: Stereogram illustrating the structure of the buccal mass. The haemocoele of the head has been laid open from in front and the left half of the oesophagus and the roof of the buccal mass removed. The radula is represented as being cut away on the left side to show the odontophoral cartilage and the arrangement of the chief muscles of the buccal mass. aft, anterior division of the foot; bcav, haemocoele of the head; cart, odontophoral cartilage; $c m$, radular caecum; $j$, jaw; $l b g$, lateral buccal gland; $m b g$, median buccal gland; $m u$ I, $m u$ 2, $m u$ 3, muscles of the buccal bulb referred to in the text; oes, oesophagus; or lp, oral lappet; ra, radula; ragr, radular groove; salg, right salivary gland. B: representative teeth of the radula. cnt, central tooth; lat, lateral teeth; marg, marginals. 
uniform teeth. The radular structure is illustrated in Fig. 5B. Each row consists of a central tooth, flanked by a series of up to Ioo laterals, with a further series of marginals towards the edges. The central tooth forms a narrow wedge, widest along its flat posterior edge, and surmounted by a single elongate cusp. The laterals are rather long and arcuate, resembling in shape the teeth of the single lateral pair of the mesogastropod radula. They have single, bluntly pointed cusps. The marginals are similar in shape, equipped with three short blunt cusps of roughly equal size. The odontophore is supported by a single horseshoe-shaped cartilage, with the two side lobes laterally compressed and giving insertion to muscles operating the radula. The substance of the cartilage is traversed by muscle fibres, which serve to compress and elongate it as the radula is protracted. The cytoplasm of the cartilage cells is permeated with fine black pigment granules, which impart a dense greyish colour to the whole cartilage.

The radular ribbon curves widely round the free edge of the odontophore, and narrows posteriorly, its edges becoming upcurved to form a shallow trough open from above. Running backwards into the radular caecum, the margins converge towards the dorsal mid-line, so that the radular membrane is rolled into an incomplete tube, extending around the lining of the caecum, attached to its epithelium. The radular caecum (Fig. $5 \mathrm{~A}, \mathrm{~cm}$ ) is a short tube, $80-90 \mu$ in diameter, passing backwards between the side limbs of the odontophoral cartilage, and emerging behind as a rounded bulb containing the tooth-secreting cells, or cuspidoblasts. At the opening of the caecum from the buccal cavity, its lumen is entered anteriorly, and along the dorsal fissure between the edges of the radula, by a long column of connective tissue; called by Carriker (1946), in Lymnaea, the 'collostyle'. This forms a central core filling the whole of the radular caecum; its rounded tip projects bluntly from the caecum into the buccal cavity.

The buccal cavity above the odontophore is wide and dorso-ventrally depressed; it reaches backwards behind the oesophagus and is floored by the radula which extends downwards at the sides of the odontophore. It is roofed in the middle line by a tapering flange of ciliated epithelium triangular in section, which fits closely from above into the trough of the radula, and dwindles towards the mouth of the radular caecum. Through the epithelium open the ducts of subepithelial mucous cells, similar to those of the lateral buccal glands. They may be referred to as the median buccal gland (Fig. $5 \mathrm{~A}$, $m b g$ ), and their secretion probably serves chiefly to pick up particles borne backwards beyond the oesophagus.

Fig. $5 \mathrm{~A}$ shows also the principal muscles of the buccal bulb. These comprise extrinsic retractor muscles, passing forward from the foot and the floor of the haemocoele to the base of the odontophore and the side walls of the buccal cavity. There is an especially large pair of radular retractors originating on the outer posterior aspects of the odontophoral cartilages, passing inwards 
beneath the cartilages, and running forwards underneath the radular caecum, on which they are inserted ventrally. Other muscles, with insertions on the inner aspects of the cartilage pass obliquely forwards, above the cartilage, to a broad insertion beneath the radular ribbon. They contract to fold the ribbon into a trough and to draw its edges together.
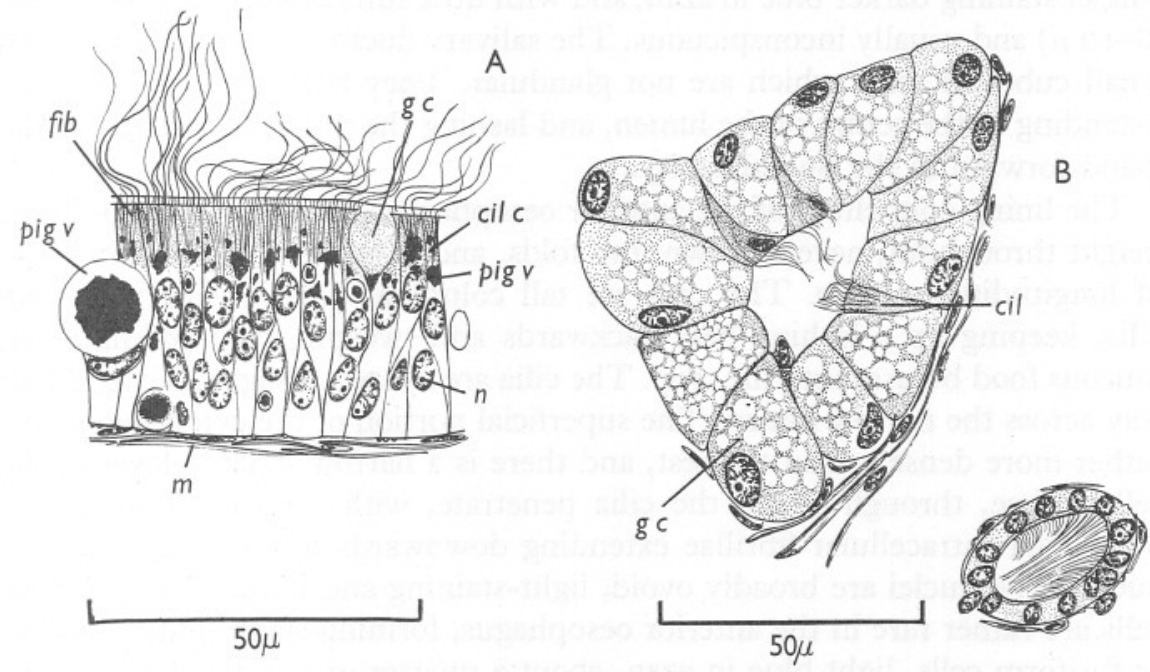

Fig. 6. Otina otis. A: epithelium of the anterior region of the oesophagus (Bouin's; azan) cilc, ciliated cell; fib, intracellular fibrillae; $g c$, glandular cell; $m$, muscle fibre; $n$, nucleus of ciliated cell; pig $v$, vacuole containing black pigment. B: Transverse section of a salivary gland, and of its duct (Bouin's; azan). cil, ciliated cell; $g c$, gland cell.

\section{The Oesophagus}

The oesophagus (Fig. $5 \mathrm{~A}$, oes) arises rather far forwards from the buccal bulb in front of the odontophore, immediately above the mouth. The odontophore when retracted lies entirely behind the oesophageal opening. The oesophagus funnels upwards from the buccal bulb, and runs back in the mid-line as a narrow cylindrical or dorso-ventrally flattened tube, 100-I20 $\mu$ in diameter. This region may be referred to as the anterior oesophagus. Immediately behind the buccal mass it terminates abruptly, and the gut widens into a thinner-walled fusiform crop, which may, at times, be strongly distended with a mass of food material.

Along either side of the anterior oesophagus, extending backwards beside the crop, lies a long salivary gland. This consists of a thick-walled tube, opaque white or slightly translucent, and tapers in front to a very fine duct which penetrates the pharyngeal roof. The structure of the salivary gland (Fig. 6B) is extremely simple: it is 90-100 $\mu$ across, cylindrical or sometimes prism-shaped by compression from adjacent structures. The lumen is surrounded by up to a dozen rows of gland cells, of a single type with rather 
coarsely reticulate cytoplasm, staining light blue in azan, grey-green in Masson's, jet black in thionin, and pink in mucicarmine. The cell contents are thus entirely mucoid in nature. The nuclei are rounded or ovoid, basal or pressed close to the side wall of the cell, and are uninucleolate. Two or three small ciliated cells usually appear in a transverse section, wedge-shaped and single, staining darker blue in azan, and with little tufts of lash-like cilia, short (8-IO $\mu$ ) and usually inconspicuous. The salivary duct is $35-40 \mu$ across, with small cuboidal cells, which are not glandular. They bear a coat of tall cilia extending to the centre of the lumen, and lashing the mucoid secretion of the gland forward to the buccal cavity.

The lining epithelium of the anterior oesophagus (Fig. 6A) is of a uniform height throughout, never thrown into folds, and is backed by a narrow layer of longitudinal muscle. The cells are tall columnar $(40 \mu)$, with very long cilia, keeping up a lashing beat backwards and sweeping and rolling small mucous food boluses into the crop. The cilia are 25-30 $\mu$ long and extend half way across the narrow lumen. The superficial portion of the cytoplasm stains rather more densely than the rest, and there is a narrow striated layer at the cell surface, through which the cilia penetrate, with a series of fine, perpendicular intracellular fibrillae extending downwards to the central row of nuclei. The nuclei are broadly ovoid, light-staining and binucleolate. Gland cells are rather rare in the anterior oesophagus, forming small, plump bodies or fusiform cells, light blue in azan, about a quarter or one-third the length of the ciliated cells and inserted between their distal tips. Granules of black pigment are incorporated in the cytoplasm to the superficial side of the nuclei; pigment may also be aggregated in rounded spherules, some of them quite large, within amoebocytic cells, which frequently wander into the epithelium from the underlying layers. When the crop is empty its wall is thrown into small, impermanent folds. Like the anterior oesophagus, the wall has a densely speckled appearance, from the presence of black pigment incorporated in the epithelial cells. The crop is marked off sharply from the anterior oesophagus, by its much greater diameter $(300-400 \mu)$ and by the reduction in size of the epithelial cells, which are short (I2-I5 $\mu$ ) with cilia of about the same length. The nuclei form a single basal row, and gland cells are infrequent, as in the anterior oesophagus. Pigment is scattered in small granules in the superficial part of each cell.

\section{The Stomach and Intestine}

The stomach (Fig. $7 \mathrm{~A}$ ) is a triangular sac, lying on the left side of the animal at the base of the visceral mass. Its left aspect is visible through the body wall, tapering in front into the proximal limb of the intestine, which runs straight forward just beneath the thin external integument. The oesophagus enters towards the mid-line on the deep aspect. For the most part, the stomach is thin-walled and transparent. Its contents are clearly visible 
through the wall, and it often becomes greatly distended when filled with recently ingested food. Towards the apex on the left side, the wall becomes rather more muscular, to form a short, pointed pouch (Fig. $7 \mathrm{~A}, m p$ ). There are two digestive diverticula, the lobules of which make up the greater part of the

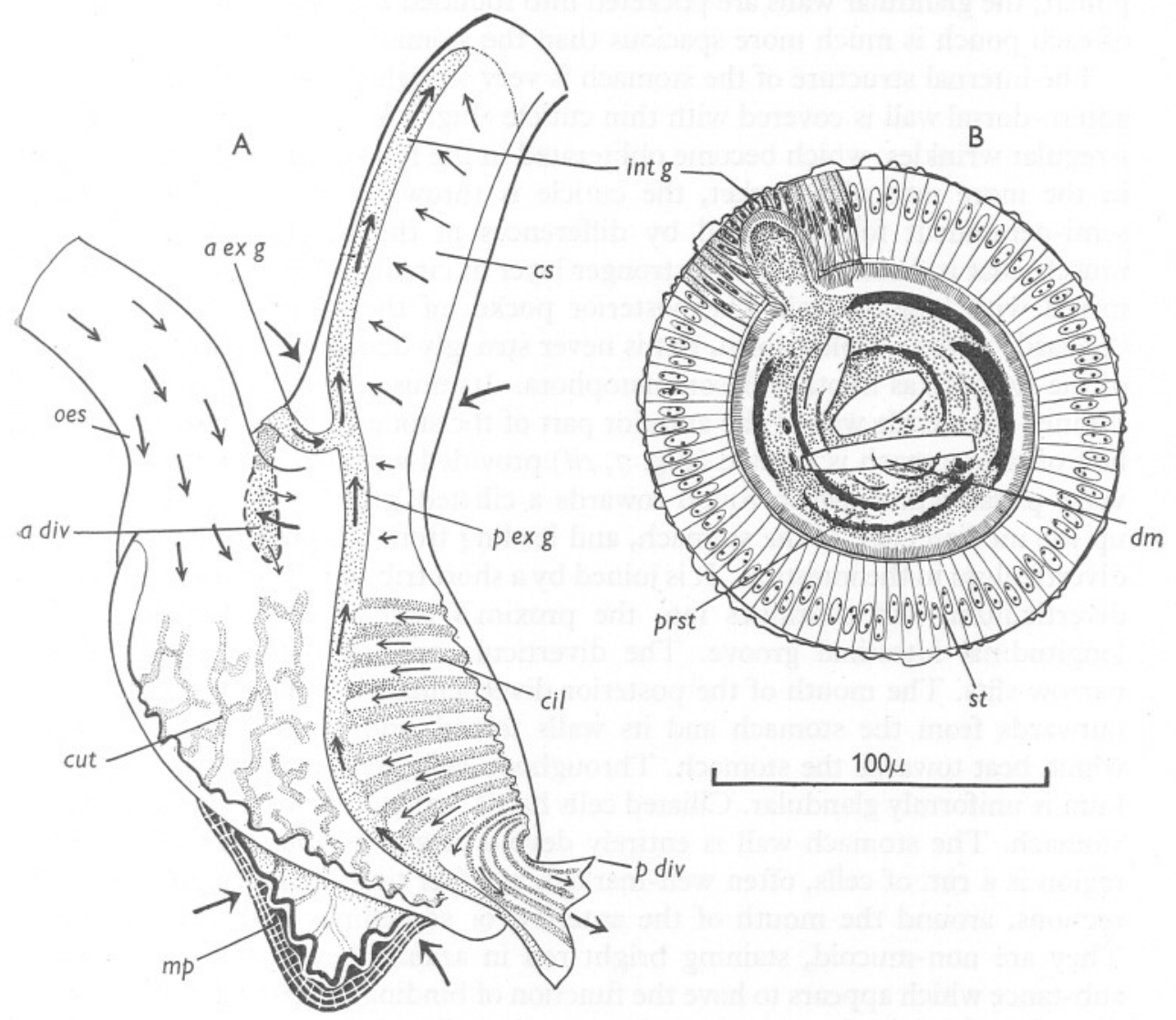

Fig. 7. Otina otis. A: the stomach, figured without dissection as a transparent object, showing the course of the ciliary currents. The heavy black arrows indicate the movement of contents into the diverticula, and (outside the stomach) the regions of the strongest muscular contraction. adiv, anterior digestive diverticulum; a exg, anterior excurrent groove; cil, ciliated area; cs, 'style sac'; cut, area of cuticle; intg, intestinal groove; $m p$, muscular pocket; oes, oesophagus; $p$ div, posterior digestive diverticulum; $p$ ex $g$, posterior excurrent groove. B: transverse section of the proximal limb of the intestine, or 'style sac'. $d m$, diatom enclosed in the mucus of the protostyle; int $g$, intestinal groove; prst, protostyle; st, epithelium of the style sac.

visceral mass. They are few in number, and each is large and rounded, or bluntly lobulate, orange or dark brown in colour, with large black spherules speckling the surface. The larger anterior digestive diverticulum opens through the antero-dorsal wall of the stomach. Its aperture is situated close to the 
entry of the oesophagus and some distance behind the origin of the intestine. The somewhat smaller posterior (morphologically left) diverticulum opens at the postero-median angle of the stomach, close to the mid-line. From each diverticulum, the individual lobules run together to form a single cavernose pouch; the glandular walls are pocketed into rounded saccules, and the lumen of each pouch is much more spacious than the stomach itself.

The internal structure of the stomach is very straightforward. The left and antero-dorsal wall is covered with thin cuticle (Fig. $7 \mathrm{~A}, c u t$ ) thrown into tiny, irregular wrinkles, which become obliterated in the full stomach. Posteriorly, in the more muscular pocket, the cuticle is thrown into several stronger, semi-permanent folds, formed by differences in the height of cells. The muscle coat is formed here by a stronger layer of circular fibres, closely intermixed with longitudinal. The posterior pocket of the stomach serves as a 'gizzard' of the simplest form, but is never strongly demarcated from the rest of the stomach as in other Basommatophora. Its muscle coat merges into the thinner contractile wall of the anterior part of the stomach. The right median half of the stomach is ciliated (Fig. 7, cil) provided with ten to twelve transverse plicae which sweep round towards a ciliated groove $(p e x g)$ running up the median edge of the stomach, and leading from the posterior digestive diverticulum to the intestine. It is joined by a short tributary from the anterior diverticulum, and continues into the proximal part of the intestine as a longitudinal intestinal groove. The diverticula open into the stomach by narrow slits. The mouth of the posterior diverticulum is somewhat pocketed outwards from the stomach and its walls folded, and lined with fine cilia, which beat towards the stomach. Throughout each diverticulum the epithelium is uniformly glandular. Ciliated cells hardly extend outwards beyond the stomach. The stomach wall is entirely devoid of glands; the only secretory region is a rim of cells, often well-marked, at other times hardly apparent in sections, around the mouth of the anterior, or sometimes both diverticula. They are non-mucoid, staining bright red in azan. They produce a viscid substance which appears to have the function of binding the particles from the digestive gland as they are carried across the ciliated lips of the diverticula into the stomach.

The strongest cilia within the stomach are developed in the excurrent grooves from the diverticula. Here a rapid current sweeps smaller particles forward into the intestine. The grooves do not themselves clear the whole of the waste material from the digestive gland; large clusters of spherules from the digestive cells frequently appear in the general contents of the stomach. The ciliated ridges are formed by variations in the height of the cells of the columnar epithelium, which reaches $30 \mu$ along the folds, but less than half this length along the furrows. There is a median row of long rod-like nuclei, tending to be more compressed in the narrower cells which constitute the folds. The cilia are short $(2-3 \mu)$ and very dense. Though individual particles 
may be swept along the furrows, the ciliated area as a whole is evidently not adapted for sorting. The primary function of its cilia is not to deal with separate particles, but to assist the rotation of the heavy bolus of stomach contents bound with mucus. The cuticle-bearing cells are stouter than the ciliated cells, and are $30 \mu$ tall, with a subcentral row of oval nuclei. The cuticle layer is thin $(\mathrm{I}-2 \mu)$, staining lightly blue with azan and is attached by a delicate layer of fine tag-like processes resembling cilia.

The proximal limb of the intestine leading forward from the stomach is very distinct in histology from the stomach and from the rest of the intestine. Its lining epithelium is of brick-shaped columnar cells (Fig. 7 B), $30 \mu$ in height, with a central row of clear-staining, ovoid nuclei, each with two nucleoli. The cytoplasm is uniformly granular and rather lightly staining. Mucous glands are never developed. The distal half of each cell is occupied by a fan of intracellular fibrillae connected with a row of short bristle-like cilia, 5-6 $\mu$ in height. The lining of the intestinal groove is, by contrast, of extremely narrow cells, of which there are a dozen or so on either side of the groove, with compressed nuclei, darker staining cytoplasm. The cilia are longer and finer, keeping up a rapid beat aborally along the intestine. The bristle-like cilia of the rest of the epithelium beat in a transverse direction. Their action is difficult to see in the excised intestine in which they are generally inert. The direction of the effector stroke is, however, often retained in the row of cilia after fixation, and this fact, together with the concentric arrangement of layers of mucus and faeces, indicates that these cilia serve to rotate the faecal rod, which fills this part of the intestine and projects into the stomach. In short, both in its structure and function, the proximal part of the intestine in Otina possesses all the features of a style-sac of the most elementary kind.

It has become clear, from the work of Graham (i949) (see also Morton, $\mathrm{I} 952 \mathrm{a}$ ) that the style-sac form of stomach is a primitive and generalized feature in the earliest members of the molluscan phylum. The most archaic members of both the gastropods (Archaeogastropoda and Cyclophoracea) and the lamellibranchs (Protobranchia) have strong cilia in the proximal part of the intestine, serving to rotate a 'protostyle', or rod of mucus and faeces projecting into the stomach. The protostyle provides the chief source of movement within the stomach, both for drawing in a food-string from the oesophagus, and for sweeping particles over the ciliary sorting area. In later evolved types in both classes, the rod may lose its faecal character and become clear and hyaline, to form the enzyme-containing crystalline style. In Otina waste particles from the stomach and 'faeces' from the digestive gland are compacted into a protostyle which is slowly rotated by cilia; particles are circulated within the stomach. The protostyle is much more coherent than the rest of the contents of the stomach, and while it rotates, it is gradually passed backwards into the intestine by the cilia of the longitudinal groove, and forms the first portion of the faecal string. The mucus of the protostyle is 
deposited in thin layers, made up from two types of secretion, the bluish staining (azan) secretion carried into the stomach from the anterior part of the gut, and the bright red-staining secretion from the cells lining the rim of the digestive diverticula.

The mode of action of the stomach of Otina, a primitive pulmonate, is thus very similar to that of the lamellibranchs Nucula (Graham, I949) and Malletia (Yonge, 1939), and of the prosobranch Murdochia (Morton, 1952b). As in the protobranchs, muscular action also plays an important part in the working of the stomach. Contractions of the wall, especially in the stouter posterior pocket, serve in part to triturate the contents of the food bolus, which is pressed firmly against the cuticularized wall. The cuticle forms a protection against abrasion by sharper fragments, and corresponds in location to the gastric shield. At the same time, regular contractions of the whole stomach wall serve to force semi-fluid material squeezed out of the food bolus (with the finest particles in suspension) into the digestive diverticula, which are, in Otina, filled chiefly by muscular action. From time to time, especially after an excretory phase of the digestive gland, the opening of the intestine shows more pronounced muscular contractions, and strong peristaltic waves nip off portions of the protostyle, which are carried backwards rapidly and added to the faecal string. Though the cilia of the intestinal groove are still active, it appears to be chiefly by these sudden muscular contractions that the faeces are driven into the intestine. In general, the food ingested by Otina comprises particles of a finer grade than in Leucophytia. Diatoms bulk large among the stomach contents, and sufficient trituration is evidently afforded by the muscular wall of the stomach, in the absence of a highly differentiated gizzard as in the Ellobiidae.

The stomach of Otina, in its structure and mode of action, appears to be the most primitive yet described in a pulmonate. It shows almost diagrammatically most of the landmarks regarded by Graham (I949) as typical of the stomach in the earliest molluscs: thus, for example, its division into ciliated and cuticularized halves (though there is no spur-like gastric shield), the presence of a 'style sac' with a protostyle, and the paired digestive diverticula with excurrent grooves converging to form an intestinal groove. The posterior gastric caecum (held by Graham to be an archaic feature) is not developed at all in Otina, unless we regard it as represented by the outpocketing of the stomach from which the posterior digestive diverticulum opens. This caecum is however present in the more primitive ellobiids (Morton, I955 $b$ ); the earliest bivalves, the protobranchs (Yonge, I939) and the Archaeogastropoda (Graham, 1949) have it also. If a posterior caecum is to be regarded as a feature of the primitive molluscan stomach, the structural simplification going with reduction in size has probably been responsible for its loss in Otina.

Further, however, the stomach of Otina clearly foreshadows the condition in the higher Basommatophora. Already it has to a large extent lost its 
reliance on cilia, and muscular action has increased in importance. At the same time, Otina serves to explain what has hitherto not been clear, the relation of the muscular pulmonate stomach to the style-sac type of stomach in prosobranchs, where the chief reliance is on ciliary systems and mucus secretion.

The 'style-sac' in Otina passes without change in diameter, into the middle region of the intestine which forms a narrow tube of uniform width $(75 \mu)$. The limb running forward from the stomach passes upwards through the anterior lobe of the digestive gland, to emerge at the dorsal surface. Here it forms a short loop, commencing along the left side, then turning sharply backwards to encircle the anterior lobe of the digestive gland behind, and running forward on the right side, to open by the anus, just in front of the pallial opening. It is lined with four to five longitudinal ridges formed by differences in cell height. The cilia beat strongly out of the grooves, and towards the anus along the summits of the ridges. The epithelial cells are columnar, $\mathrm{I} 2-\mathrm{I} 5 \mu$ in height, the ciliary coat $5 \mu$ tall. Mucous glands are rather few, plump and fusiform in shape, and contain small clusters of secretion droplets staining bright red in azan. The subepithelial layer is only sparsely muscular, but the faecal string is moulded by intermittent muscular action, and carried backward by peristaltic waves, as well as by the continuous fast beating of the cilia. The ridges which line the intestine are temporarily flattened as the string is passed along. The rectum differs from the middle intestine in its usual lack of folds, its shorter cells ( $10 \mu$ ) and longer cilia $(7-8 \mu)$. The gland cells are of the same kind but are a good deal more numerous, filled with separate secretory spherules and constricting the narrow ciliated cells. Their secretion provides the final mucous covering of the long rope of faeces. The muscle coat is rather better developed than in the middle intestine, and the whole, or at least long portions, of the faecal string may be voided by peristaltic waves at one time. As compared with the prosobranchs, the faecal string in Otina is only loosely compacted. It is never compressed into separate pellets, and, by reason of the external position of the anus, there arises no problem of the fouling of the pallial cavity by voided faeces.

\section{The Digestive Gland}

The digestive diverticula in Otina are the site of both absorption and enzyme production; they have also an excretory role. The lining epithelium, from the stomach to the tips of the tubules, is glandular, and contains cells of two chief types, digestive cells in greater numbers, interspersed with smaller groups of excretory cells. At the absorptive phase of the digestive gland (illustrated in Fig. 8A), the cells are for the most part short and columnar, of a uniform height $35 \mu$, with rounded or suboval nuclei lying slightly above the basement membrane. The largest of the excretory cells are broad-based 


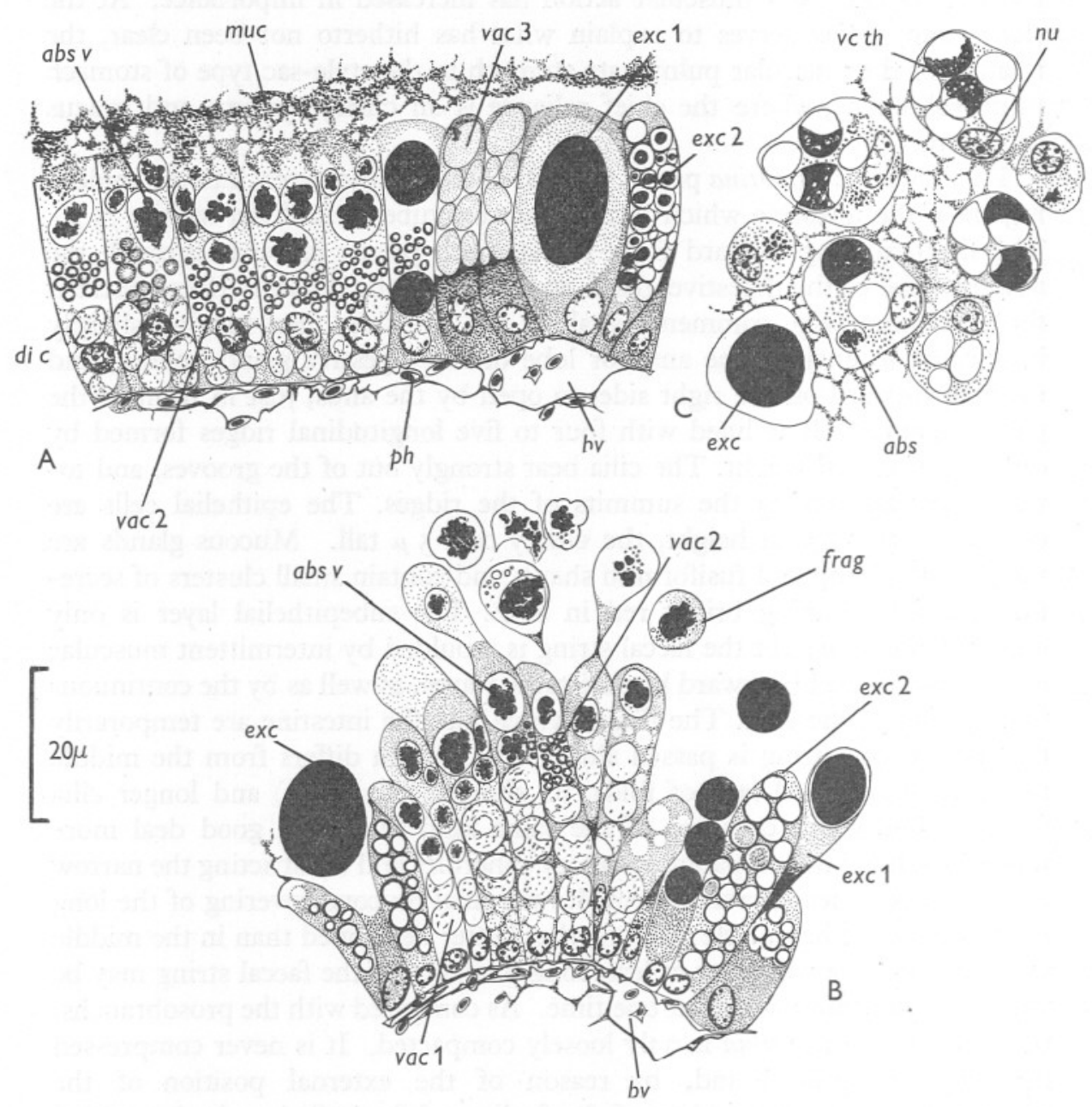

Fig. 8. Otina otis. A: epithelium of the digestive gland, at the phase of absorption. B: the same at the phase of fragmentation and excretion (Bouin's; azan). absv, food vacuoles loaded with absorbed material from the lumen; $b v$, blood vessel; dic, digestive cell; exc, excretory spherule extruded from a cell; exc I, excretory cell of the first type; exc 2, excretory cell of the second type; frag, fragmented tip of digestive cell constricted off into the lumen; muc, mucus from the stomach, with finely divided food material in suspension; $p h$, phagocytic blood cell; vac I, basal vacuole of the digestive cell; vac 2, smaller excretory (?) vacuoles in the digestive cells; vac 3, blue-staining (azan) vacuoles in the excretory cells at the absorbing phase. C: 'fragmentation phagocytes' formed by abstriction of nucleated portions of the digestive cells, suspended in mucus within the stomach. $a b s$, granules of absorbed material from stomach; exc, excretory spherule; $n u$, nucleus of 'phagocyte'; $v c t h$, basal vacuole of digestive cell (after thionin staining) with stained surface 'membane'. 
and triangular, and as a rule may be distinguished from the digestive cells by the larger size of the nuclei $(5-6 \mu)$.

The digestive cell (Fig. 8, dic) contains several types of inclusion; its free border is flat and entire at the ingesting phase, and the cytoplasm near the surface is filled to a depth of $4-5 \mu$ with the mucoid material containing suspended food particles, with which the lumen of the tubule is distended. This material is being freely taken up along the whole surface of the digestive epithelium, so that the cell border is often obscured, the cytoplasm taking on the same coloration (blue in azan, green in Masson's) as the contents of the lumen. Below the ingesting region, the cytoplasm is filled with large spherical vacuoles, 6-7 $\mu$ across, as a rule two or three deep in each cell, a single vacuole filling the whole cell width. Many of these vacuoles contain droplets of ingested material. They are in some places small and no more than $\mathrm{I}-2 \mu$ across, elsewhere clumped together in irregular clusters, or coalescing into a spherule filling the whole vacuole. The rest of the vacuoles remain colourless with most stains, including azan, haemalum, Masson's and mucicarmine. They stain strongly, however, with thionin, which could be employed to distinguish them from all other cell inclusions of the digestive gland. Their appearance after thionin is shown in Fig. $8 \mathrm{C}$; the vacuole consists of a colourless and structureless central sphere, surrounded by a thin membrane which in fixed material almost always ruptures and peels away at one or more points. With thionin the membrane becomes deep indigo blue; with other stains it presents merely an uneven refractile surface, colourless or pale golden-yellow. At the base of the digestive cell, clustered around and sometimes below the nucleus, is another zone of these thionin-staining vacuoles, of rather smaller diameter ( $v a c$ I), perfectly colourless, without trace of ingested contents. They sometimes extend into the middle of the cell but usually, above the nucleus, are to be found inclusion spherules of a third type, of smaller size $(2-3 \mu)$ pinkish brown in living macerations and retaining the same colour in azan or haemalum. These are evidently excretory in character, though it is not certain whether they are extracted from the blood or represent the final indigestible residue of material absorbed from the lumen.

Excretory cells appear, at the absorptive phase of the digestive gland (Fig. 8, exc) to be represented by three stages. The largest are pyriform, strongly expanded towards the tip, and each containing a large, black or dark brown, excretory sperule $15-20 \mu$ in diameter. In each cluster of excretory cells appear one or more columnar, round-tipped cells, filled with twenty to thirty light brown or pink spherules, contained in separate, clear-staining vacuoles. These spherules may sometimes be discharged separately in the lumen, although, as a rule, the columnar cell appears to be an earlier stage of the pyriform cell, in which a single large spherule is later formed by the coalescence of the smaller ones. The remaining excretory cells are also columnar during the ingesting phase, the basal half of the cytoplasm being pinkish 
in azan, or violet with thionin. The distal half is filled with rounded or ovoid vacuoles, 5-6 $\mu$ across, which do not stain with either thionin or azan.

At the excreting phase (Fig. $8 \mathrm{~B}$ ) the epithelium of the digestive gland takes on a rather different appearance. The digestive cells become longer and round-tipped. They bulge strongly into the lumen and their free tips now begin to be constricted off, forming spherical fragments of cytoplasm ( frag) loaded with blue-staining (azan) contents. This material would seem to represent an indigestible residue of the mucus-borne particles that were previously absorbed into the digestive vacuoles. The smaller pink spherules appear to be shed also by fragmentation or rupture of the cell wall, while the remaining basal part of the cell is occupied by the large thionin-staining vacuoles. The larger excretory cells containing the densely black spherules have now become greatly distended, some with a row of two or three spherules, others with a single large one. These are shed into the lumen by rupture or by fragmentation of the cell. The smaller columnar excretory cells are either packed entirely with purplish brown spherules; or their basal halves may be of uniformly staining cytoplasm, pink in azan, violet in thionin, while the distal end develops separate pinkish spherules, as in the excretory cells at the earlier phase (Fig. 8A).

In Otina the spherical fragments of digestive cells, cast off during the excretory phase, appear for the most part to be rejected particles laden with waste material. On reaching the stomach, they become plastered on to the protostyle or pass directly into the intestine. In some individuals of Otina, however, sectioned after 2 days' starvation, the digestive epithelium presented a ragged, highly fragmented appearance. The stomach was filled with a watery mucus, containing, together with excretory spherules, large nucleated portions, roughly spherical, or of rather irregular shape, derived from the bases of the digestive cells. The nuclei were generally polar in position, and the cytoplasm was vacuolated and filled with clear-staining spherules, giving the thionin reaction, like those of the basal parts of the digestive epithelium (Fig. 8C). These fragments of the digestive gland are of interest in closely resembling the 'phagocytic cells' described by Millott (I937) in the nudibranch forunna, as originating by abstriction from digestive cells. Forrest (I95I) has also observed them in a number of other dorids. They differ from the fragments of the digestive gland extruded into the stomach in prosobranchs, and the constricted tips of the digestive cells in Otina, in retaining nuclei, and, according to Millott, presumably some power of free movement. In forunna they absorb, and in part digest, such particles as introduced blood corpuscles within the stomach, providing, as it were, a means of non-localized intracellular digestion. In Otina, from the small size of the stomach and the difficulty of introducing experimental foods, no evidence could be gained as to their role in digestion. Their thionin-staining vacuoles may be presumed, as in the digestive cells, to be the source of enzymes. 
From the following experiments, it is clear that the stomach in Otina contains active enzymes.

The substrate employed was the gelatin film of a developed photographic plate. Whole digestive glands, and separate stomachs from which all traces of digestive glands had been carefully removed, were pressed out on the plate and kept moist under cover-slips. The stomachs selected were empty of food or detritus, and filled with watery mucus containing yellowish brown cell fragments from the digestive gland. After $24 \mathrm{~h}$, the gelatin film beneath the crushed stomachs had been in each case completely and cleanly digested away. Digestion by the stomach fluid proceeded in fact much more rapidly than by the macerated digestive glands themselves, where the gelatin became much softened but only slightly eroded from the plate. Obviously, in Otina, digestion is by no means all intracellular, and material absorbed by the digestive cells has evidently undergone previous breakdown by enzymes in the stomach. Enzymes are active in the stomach after a day's starvation, and it would appear that their origin is to be sought in the so-called 'fragmentation phagocytes' derived from the digestive cells.

Wandering amoebocytic cells from the subepithelial blood cells appear to play little or no part in digestion in Otina, either in the stomach or in the digestive gland. In the wall of the stomach they are extremely scarce or absent. This is in contrast to their frequent presence in prosobranchs (Struthiolaria (Morton, I95I)); Lunella (Turbinidae) (Morton, unpublished) and in lamellibranchs (Yonge, I926). They appear to be characteristic of stomachs with wide ciliary sorting surfaces, and often wander through the epithelium of the sorting area in very large numbers. Their comparative absence in Otina and in opisthobranchs may be correlated with the reduction in importance of the sorting area. Ciliary sorting and amoebocytic ingestion appear as a rule to go hand in hand.

\section{REPRODUCTIVE SYSTEM}

Like the Ellobiidae dealt with in a previous paper, O. otis is a protandrous hermaphrodite. The genital system is of the most primitive type found among the pulmonates; the duct is undivided and hermaphroditic throughout, except for a bifurcation into male and female channels at the extreme anterior end, in front of the glandular genital mass, and only a short distance behind the external openings. As in Leucophytia, the gonad shows a marked occurrence of two phases, a sperm-producing phase occupying the autumn and earlier winter, followed by an egg-producing phase culminating in oviposition. The condition of protandry is most evident from the condition of the gonad itself; the glandular genital tract reaches its female condition in advance of the completion of spermatogenesis, and at no time during sexual maturity are the female ducts absent. The prostate, however, always displays its greatest 
development during the male phase, and is reduced during the female phase, when the development of the albumen gland and mucous gland is accentuated. For the sexual development of Otina otis over a single reproductive season, a cyclic diagram may be constructed which differs in scarcely any feature from that presented for Leucophytia (Morton, I955a).

The arrangement of the accessory glands is illustrated in Fig. 9. The little hermaphrodite duct conveys sex products from the gonad, to open into the large or glandular hermaphrodite duct. The albumen gland opens into the large hermaphrodite duct at the same point. The proximal part of the large hermaphrodite duct forms the posterior mucous gland. As it runs farther forward, the duct retains its single lumen, though it is divisible on histological grounds along its whole length into an anterior mucous gland, constituting the female tract, and a prostate, forming the male channel. A non-glandular conducting tube, the distal common duct, takes its origin from the region of the anterior mucous gland and prostate, and continues forward along the floor of the haemocoele, towards the right side of the head. It divides anteriorly into a narrow vas deferens and vagina. From the vagina, just in front of this bifurcation, arises a large bursa copulatrix. A second sperm storage sac, the accessory bursa copulatrix opens by a long stalk from the distal common duct, immediately behind the origin of the vagina and vas deferens. Pelseneer's short description and figure (I90I) is thus fairly accurate in outline, though the albumen gland and posterior mucous gland are indicated only diagrammatically, and the relations of the anterior part of the tract are not shown in detail. No previous account exists of the histology or functions of the genital tract of Otina.

The hermaphrodite gland or ovotestis forms a single pouch lying on the concave surface of the visceral spire, applied to the posterior lobe of the digestive gland. Its cavity is partly divided by thin trabeculae of connective tissue bearing the germinal cells and giving to the gonad externally the appearance of a cluster of rounded follicles. The first part of the little hermaphrodite duct is a narrow transparent tube, which courses forward ventrally, close to the mid-line, and before reaching the albumen gland becomes strongly convoluted, its coils often being distended and sacculated (lhd). These coils are opaque white through the greater part of the year, containing large amounts of stored sperm, and thus function as a simple vesicula seminalis. The epithelium is of simple columnar or cubical cells with round nuclei and with a long ciliary coat. There are no glands, and only a very sparse muscle coat, two or three fibres in thickness, both longitudinal and circular. Resorption of sperm was never observed, nor do the sperms become orientated.

The structure of the large hermaphrodite duct may be followed from Fig. 9. The little hermaphrodite duct opens into it at the base of the posterior mucous gland ( $p m u c$ ) which forms a rounded translucent sac, lying to the right side of the oesophagus, about half way along the trunk, beneath the thin pallial floor. The albumen gland ( $\mathrm{llb} g$ ) is applied to the posterior mucous gland 


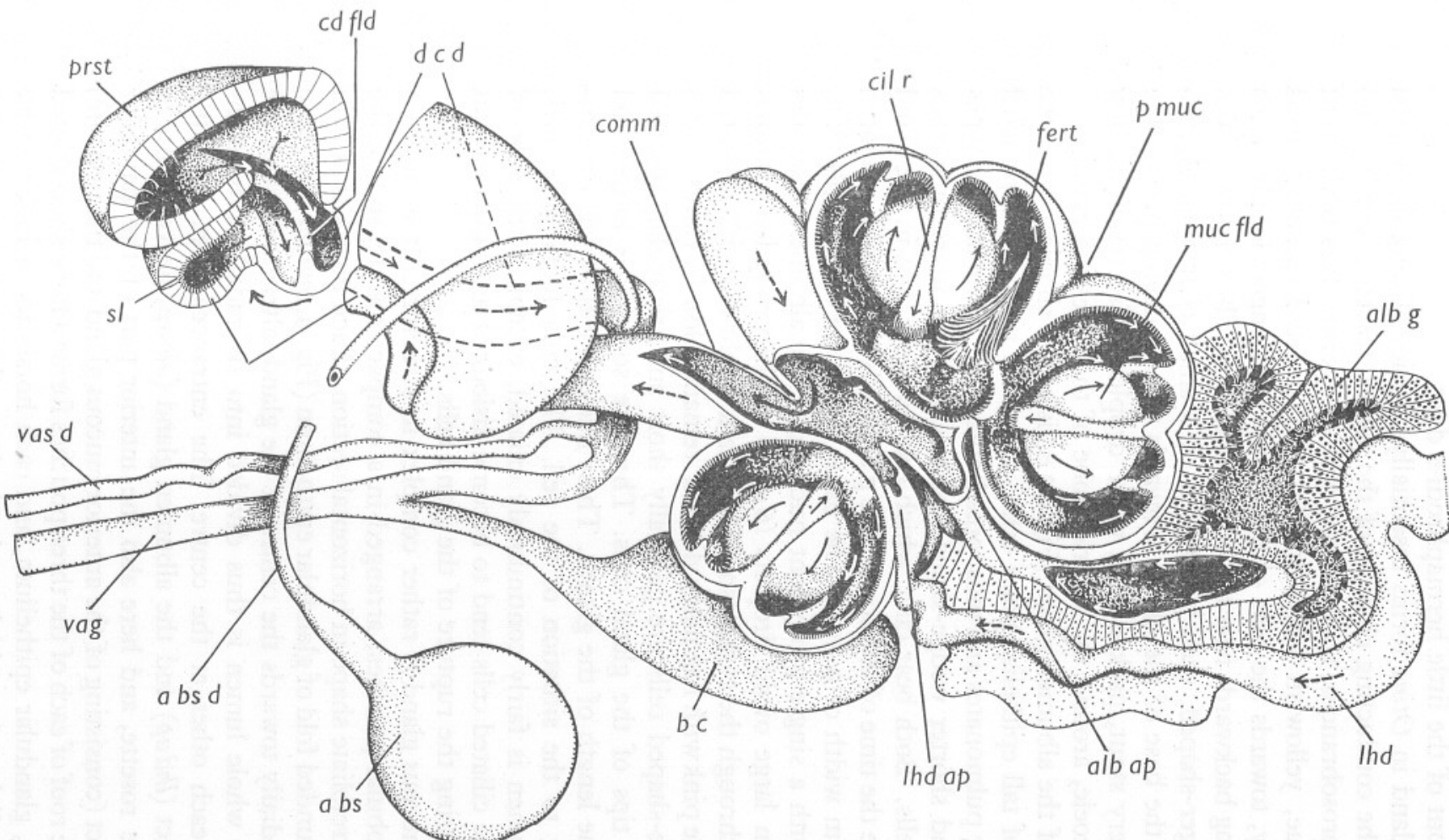

Fig. 9. Otina otis. Stereogram of the glandular regions of the genital tract, viewed from the median aspect and dissected to show the internal structure and the course of the ciliary currents. The anterior-most part of the albumen gland is represented in longitudinal section; the roof of the posterior mucous gland has been removed; and the prostate with the anterior mucous gland and distal common duct has been cut across transversely and the two halves separated to show the relations of the three ducts. The anterior parts of the vagina and vas deferens, with the penis, have been omitted. $a b s$, accessory bursa copulatrix; $a b s d$, duct of the accessory bursa copulatrix; albap, opening of the albumen gland into the posterior mucous gland; albg, albumen gland; comm, communication between the anterior and posterior mucous glands; $b c$, bursa copulatrix; cdfld, longitudinal fold dividing the cavity of the distal common duct; cilr, ciliated ridge running round a fold of the posterior mucous gland; $d c d$, distal common duct; fert, fertilization pouch; lhd, little hermaphrodite duct; lhd ap, opening of the little hermaphrodite duct into the posterior mucous gland; mucfld, glandular fold of the posterior mucous gland; $p m u c$, posterior mucous gland; prst, prostate; $s l$, longitudinal slit by which the prostate and anterior mucous gland communicate; vag, vagina; vasd, vas deferens. 
behind, opening directly through its ventral wall by a short wide duct, immediately in front of the little hermaphrodite duct.

The albumen gland in Otina forms essentially a series of long diverticula discharging into the conducting channel of the genital tract; its cavity is no longer, as in the prosobranchs, traversed by eggs or sperm. It is built up of a series of opaque, yellowish white lobules, which are irregularly fused together anteriorly, towards the base of the gland. The longest lobule forms a thick strap passing backwards near the ventral mid-line. The smaller lobules are blunt and finger-shaped, each penetrated by a small cleft opening into a wider lumen at the base of the gland. Towards the egg-laying period, the lobules become very stout, packed with white droplets of secretion, tightly filling the haemocoele, around the anterior lobe of the digestive gland.

The histology of the albumen gland (Fig. Io A) is of the simplest type; the lining is formed of tall epithelial gland cells, and there are no subepithelial glands as in higher pulmonates and most opisthobranchs. There are two types of cell, smaller and shorter wedge-shaped cells, and much more numerous columnar gland cells. Both bear cilia, which are, however, lost in the gland cells shortly before the time of secretion. The gland cells are 40-50 $\mu$ in length and have a uniform width of 9-10 $\mu$. The basal nuclei are almost spherical, darkly staining, with a single prominent nucleolus. The albumen spherules range in size from large ovoid droplets $(6 \mu)$ to smaller rounded granules scattered densely through the cytoplasm. They stain bright red with azan, red with Masson's, pale pink with haematoxylin, and remain colourless after mucus stains. The wedge-shaped cells are generally short and triangular, inserted between the free tips of the gland cells. They are sometimes longer and attenuated, half the length of the glands. Their nuclei are spherical or compressed according to the situation of the cell. The cilia form long tufts, 8-Iо $\mu$ tall; the lumen is fairly continuously ciliated, except at the time of secretion, when the ciliated cells tend to become dislodged and squeezed out into the lumen, during the rupture of the gland cells.

The posterior mucous gland is rather complex in structure. It is built up of three plump globular pouches, arranged in a compact rosette, so that the whole gland is of trefoliate shape in horizontal section. Each pouch is in turn subdivided by a rounded fold of glandular epithelium (Fig. 9, mucfld) the three folds extending radially towards the centre of the gland, alternately with the pouch walls. The whole lumen is thus divided into six radial clefts, communicating with each other at the centre. The entrances from the little hermaphrodite duct $(l h d a p)$ and the albumen gland ( $a l b a p)$ lie ventrally, at the middle of the rosette, and here also the anterior part of the glandular hermaphrodite duct (consisting of the anterior mucous gland and the prostate) makes its exit. The roof of each of the three pouches forms a horseshoe-shaped tract of thickened, glandular epithelium, and each horseshoe is indented by a tongue-shaped radial groove which marks the base of the internal fold. The 
outer wall of each pouch is of ciliated and glandular epithelium, I5-20 $\mu$ in height. The dividing fold is formed by a septum of connective tissue with sparse muscle fibres. On either side of the septum arises a hemispherical group of gland cells $(25 \mu)$ with rounded, basal nuclei. Their contents are colourless or pale blue in azan, bright red in mucicarmine and black with thionin (Fig. IOB). Interspersed with the gland cells are ciliated cells, narrow and tapered, but somewhat shorter than the glands. Their nuclei are compressed and rod-like and the cells broaden at the free surface to bear a tuft of short cilia. The mucous cells become very plump during their secretory phase, but are at other times much less developed, and the glandular fold is only slightly thicker than the rest of the lining of the pouch. Around the mid-line of the fold runs a narrow ridge (Fig. 9, cilr) made up wholly of ciliated cells. These form a wedge-shaped cluster in section, fanning out from the edge of the septum of connective tissue. The ciliary currents in the mucous gland are shown in Fig. 9. Over each hemisphere of gland cells, currents beat downwards towards the base of the fold, while along the bottom of each fissure runs a narrow ridge $(r i)$ along which currents beat inwards towards the centre of the lumen. Along the ciliated tract cilr, running round each fold, the ciliary beat is also radial, towards the middle of the mucous gland.

It appears that the eggs pass through each of the three pouches of the posterior mucous gland in succession, receiving thin mucoid capsules before being carried forward into the anterior mucous gland. At the centre of the posterior mucous gland, where the little hermaphrodite duct opens, the paths followed by the eggs and sperm become separated. Sperm is directed forward into the anterior mucous gland-prostate portion of the common duct, and bypasses the mucus-secreting pouches. From the arrangement of the pouches, it would appear that the eggs first pass from the central lumen into the fertilization pocket (Fig. 9, fert) which is a wide dorso-ventral slit, formed simply as an outgrowth of the lateral pouch of the mucous gland. It is lined with columnar epithelium, $30 \mu$ tall, which contains no glands, and is distinguished by its very long cilia ( $100-\mathrm{I} 20 \mu$ ), extending in a flame-like tuft through the whole length of the slit. The fertilization pocket is directly continuous at its entrance with the wide duct of the albumen gland; its columnar cells merge into the shorter ciliated epithelium, which lines the albumen duct and isolated cells with albumen granules sometimes occur amongst the cells at the base of the ciliary flame. The cilia of the fertilization pocket could not be induced to beat in excised material; but the function is probably to expel the fertilized eggs, with their albumen coat, into the remaining portion of the mucous gland. The eggs appear to pass next through the two divisions of the posterior pouch, thence through the middle pouch, and arrive finally, surrounded by a mucoid capsule, in the anterior compartment of the lateral pouch. From the anterior wall of this pouch, a wide slit communicates with the anterior mucous gland-prostate division of the genital tract. Sperm as well 
as ova are conveyed forward along this channel by a common duct which first runs towards the mid-line in a long $\mathrm{V}$, then turns obliquely forwards. The sperm then pass along the prostatic side of the duct, and the eggs along the anterior mucous gland.

The anterior mucous gland $(a m u c)$ and the prostate $(p r s t)$ lie together on the right side, ventro-laterally to the pharynx, and immediately beneath the thin epithelium of the pallial cavity. The prostate is the more superficial; it is broad and dorso-ventrally compressed, arched against the pallial floor, and is kidney-shaped, convex laterally and concave towards the mid-line. The prostate terminates bluntly at either end; its lumen is spacious, and leads by a wide longitudinal slit, along the concave side, into the anterior mucous gland. The two glands are in open communication for some three-quarters of their common length. The histology of the anterior mucous gland is essentially like that of the posterior. The secreting cells, however, stain deeper blue with azan, and they become distended with mucus at an earlier stage. This portion of the duct is very enlarged and tumid immediately before egg-laying; its cells produce the mucous mass with which the egg capsules are surrounded.

The lining epithelium of the prostate (Fig. IoD) is simple and unfolded, consisting of a single layer of very characteristic secreting cells. These are tall, and stoutly columnar $(50 \times 10-20 \mu)$, and thus a good deal larger than the cells of any other region of the genital tract. Some of the cells are especially wide, and narrowly compress their neighbours. In vertical section they are rectangular or broadly ovoid; the free surfaces are either entire, or broken by the discharge of contents, often bulging convexly into the lumen. The basal nuclei are exceptionally large (го $\mu$ ), almost spherical, though sometimes compressed against the base of the cell. They are densely granular and stain darkly in azan and iron haematoxylin, with two prominent nucleoli. The distal two-thirds of the cell are filled with rounded or irregular secretion granules, averaging 7-8 $\mu$ across, closely crowded in the cytoplasm. They stain bright blue in azan, green in Masson's, remaining colourless after haematoxylin or stains for mucus. The prostatic secretion evidently serves as a nutritive component of the semen and can be recognized, persisting with foreign sperm in the bursa, long after copulation. The basal portion of the cytoplasm, in which the nucleus lies, is coarsely but uniformly granular, without separate inclusions, and stains lightly pink in azan. Ciliary cells are rather scarce in the prostate. They form little triangular wedges filled by small compressed nuclei ( $5 \mu$ in length) between the tips of the glandular cells. Their cilia are extremely long, forming whip-like tufts $(40-50 \mu)$ trailing into the lumen, and helping to lash the secretion forwards. Beneath the epithelium, the prostate has a rather strong coat of circular muscle, ten to twelve fibres deep, and reaching 5-6 $\mu$ across.

The anterior mucous gland and the prostate are accompanied along their whole length, by a third, and much smaller tube, the distal common duct 
(Fig. 9, $d c d$ ). This lies underneath the prostate and immediately lateral to the mucous gland, but is not itself glandular. It is muscular-walled and lined with long cilia, and originates anteriorly from both glands together, towards their blunt, anterior ends. Running at first backwards, the distal common duct soon becomes quite separate from both the mucous gland and the prostate. It conveys both sperms and ova to a point level with the posterior end of the prostate and then turns sharply forwards to run towards the head. The stereogram (Fig. 9) shows the relations of this duct to both the mucous gland and the prostate. Its wall is thrown into three or four impermanent longitudinal folds, and anteriorly, towards the opening from the prostate and mucous gland, its lumen becomes divided by a tall longitudinal fold of the ventral wall; and the duct dilates to about the same diameter as the tapered anterior end of the mucous gland. The prostate and the mucous gland are themselves partly divided by a large fold, which projects obliquely across their common lumen. Anteriorly, the ventral fold of the distal common duct fuses along its free edge with this dividing fold, so as to separate completely the lumen of the prostate from that of the mucous gland, and to form a separate opening from each into the distal common duct. Thus, on the right, a long fissure from the prostate opens into the right compartment of the common duct; into the left compartment opens the mucous gland by a slit-like aperture, which extends forward beneath the prostate, as far as the blind anterior end of the common duct. Farther backwards, the distal common duct narrows, and becomes quite closed off; the dividing fold along its ventral wall disappears. By the division of this duct at the openings from the glandular tract, eggs and sperm are directed separately into the common conducting channel. The subepithelial layers are strongly muscular, and access from either the prostate or the mucous gland can be closed off at need, by approximation of the edges of the slit leading to the distal common duct.

Opposite the posterior end of the prostate, the distal common duct runs down ventrally, and gives off the narrow duct of the accessory bursa copulatrix (Fig. 9, $a b s d$ ). It then plunges beneath the sheet of transverse muscle flooring the haemocoele, and runs forward, just beneath the body wall, along the right side of the foot, below the line of fusion of the mantle with the body wall. Almost at once it divides to form two narrow conducting channels, a dorsal vas deferens (vasd) and close beneath it, the vagina (vag) rather more distensible, but normally of the same diameter as the male duct $(30-40 \mu)$. The lining of the vagina varies a good deal according to its state of contraction. As a rule, to within a short distance of the female opening, it is little folded. It is lined with tall columnar cells, with long, rather sparse cilia. There are no gland cells. The muscle coat includes both longitudinal and circular fibres. Just after the departure of the vas deferens, the vagina gives off from its ventral wall a narrow duct, of the same histological structure, with a strongly muscular wall. This duct passes back to enter the haemocoele, and, turning 
towards the mid-line, expands into an ovoid, dorso-ventrally flattened sac, the bursa copulatrix. The vagina opens by a small, ventrally directed aperture, at the base of the foot, concealed beneath the right oral lappet. Close to the aperture its wall becomes much more distensible than farther back; the epithelium lower and thrown into triangular folds, mainly from differences in the size of the component cells. The long cilia beat outwards, carrying away waste secretions, and probably assisting the muscular contractions of the wall in oviposition.

The short vas deferens has a strong coat of circular muscle. It is lined with tall, ciliated epithelium rather resembling that of the vagina. The cilia are long, reaching the centre of the lumen. The vas deferens runs close to the vagina as far as the female aperture, at the side of which it turns inward to run alongside the penis. The male aperture is a small pore, separate from and just mesial to the female opening. It leads into a short muscular tube, which represents the invaginated penis. The intromittent organ in Otina has perhaps. the simplest structure yet observed in any pulmonate. The penial tube is perforated at its tip by the vas deferens, and when everted, has a length about equal to that of the vagina as far as the bursal duct. There is no retractile papilla, and the organ forms, in the terminology of Hubendick (I945) a 'pseudopenis'. When invaginated it curves obliquely backward in the body wall, passing mesially to the penial nerve, and to the nerve arising from the cerebral ganglion and going to the oral lappet. Its apex forms a small bulb, lying in the cephalic haemocoele, in contact with the mesial surface of the right cerebral ganglion, close against the roof of the buccal mass. The retractor muscle is a slender strap, running to the left across the pharynx, and inserted on the floor of the trunk, midway along the body cavity.

The penial tube is circular in section, $80 \mu$ in diameter, near the middle of its length. Towards the male opening, its lining is sparsely ciliated, elsewhere thinly cuticularized. Its epithelium forms six triangular longitudinal folds, with underlying muscle fibres. The circular muscle layer forms a prominent external coat. The vas deferens runs to the tip of the penial tube through the connective tissue of one of the folds; it forms here a very narrow tube, $12 \mu$ across, and its dense cilia fill the whole lumen.

Of the two sacs for the storage of sperm, the vaginal bursa copulatrix is the larger ( $b s c)$, and receives foreign sperm after copulation. It lies closely against the floor of the haemocoele, ventrally to the mucous gland on the right side. The bursa and its duct are both muscular, serving, together with the pressure of blood in the haemocoele, for the expulsion of sperm into the vagina. The duct forms an effective sphincter controlling the release of stored sperm. After copulation, the bursa contains a mass of living sperm, never oriented or attached to the epithelial cells. There is also a large amount of prostatic secretion which may persist for a time after the sac has emptied of sperm. The lining epithelium (Fig. Io C) is composed of simple columnar cells of uniform 

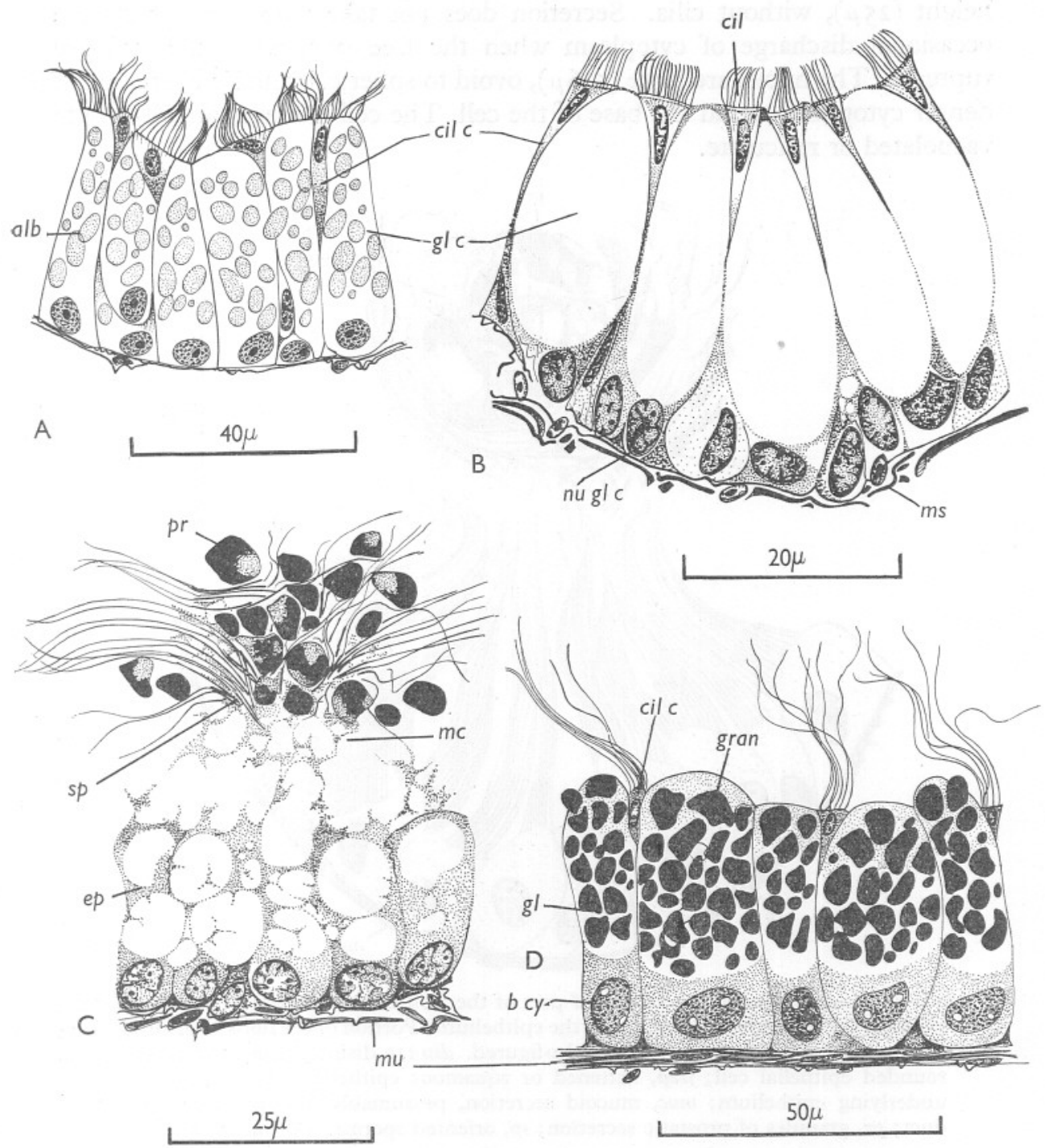

$50 \mu$

Fig. Io. Otina otis. A: histology of the albumen gland (Bouin's; azan). alb, droplets of albumen secretion; cil c, ciliated cell; $g l c$, gland cell. B: histology of the posterior mucus gland (Bouin's; Masson's trichrome). cil, cilia; cilc, ciliated cell; glc, gland cell; ms, muscle fibre; nuglc, nucleus of gland cell. C: histology of the bursa copulatrix (Bouin's; Masson's trichrome). ep, epithelial cell; $m c$, mucus material of seminal fluid; $m u$, muscle fibre of subepithelial layer; $p r$, granules of prostatic secretion; $s p$, sperms. $\mathrm{D}$ : histology of the prostate (Bouin's; azan). bcy, denser basal cytoplasm of a gland cell; cilc, ciliated cell; $g l$, gland cell; gran, granules of prostatic secretion; $m u$, coat of circular muscle. 
height $(25 \mu)$, without cilia. Secretion does not take place, except by the occasional discharge of cytoplasm when the free surfaces of the cell are ruptured. The nuclei are large $(5-6 \mu)$, ovoid to spherical, and lie in an area of denser cytoplasm round the base of the cell. The cell contents are elsewhere vacuolated or reticulate.

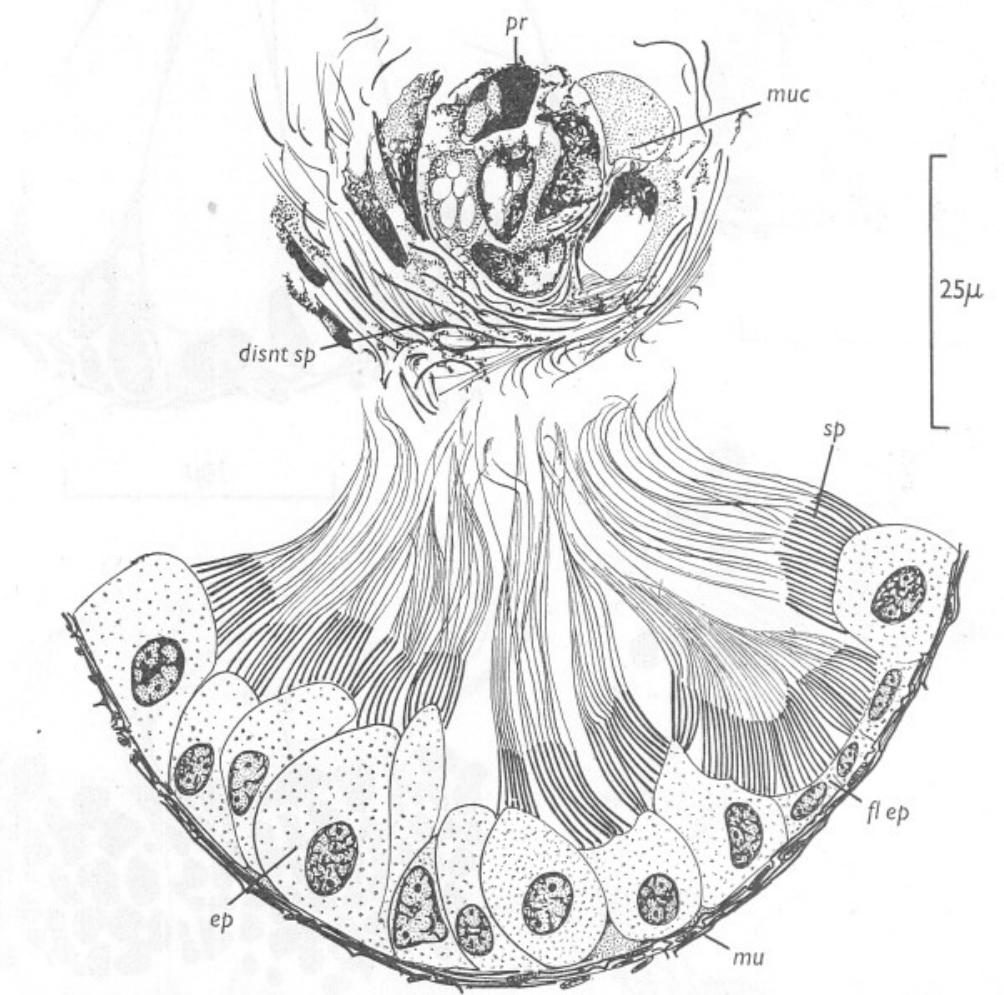

Fig. II. Otina otis. Transverse section of part of the wall of the accessory bursa copulatrix, showing the attachment of sperms to the epithelium. Portion of the mass of disintegrating contents at the centre of thelumen is also figured. disnt sp, disintegrating sperms; $e p$, larger, rounded epithelial cell; flep, flattened or squamous epithelial cell; $m u$, muscle fibres underlying epithelium; muc, mucoid secretion, presumably derived from the genital duct; $p r$, granules of prostatic secretion; $s p$, oriented sperms. (Bouin's; azan.)

Arising from the distal common duct, the duct of the accessory bursa copulatrix sweeps across the dorsal surface of the prostate, and passes obliquely backward towards the mid-line. It expands gradually into a terminal sac, I $50-200 \mu$ in diameter (Fig. 9, abs) which is hidden from dorsal view by an overlying lobe of the digestive gland. The lining epithelium (Fig. II) is of a rather distinctive kind; the cells may be in places flattened or squamous, especially during distention by sperm, but more often are plump and rounded, bulging freely into the lumen, the largest cells deeply indenting 
their neighbours. The nuclei are extremely large and rounded, with two nucleoli, central in position or displaced upward by compression. There are no gland cells, but, as in the vaginal bursa, cytoplasm may be released by rupture of the cell walls. From December until May, the accessory bursa is filled with sperm which are attached in clusters to the epithelial cells by their filiform heads. They also become attached to the flattened cells lining the duct, within a short distance of the terminal sac. In the middle of the lumen is usually a compact bolus of disintegrating sperm, appearing pinkish brown through the transparent wall. It consists of sperm heads, intermixed with fragments of cells, and with layers of mucoid and prostatic secretion.

Sperm do not appear to remain long in the vaginal bursa after copulation. Living sperm are evidently stored for some time within the accessory bursa; but whether sperm from this sac travel farther up the genital tract to the fertilization pouch, or whether fertilization is effected by sperm newly released from the vaginal bursa, is still uncertain. Copulation, however, seems to occur several months in advance of oviposition, and the prostate becomes smaller and ceases to secrete by the end of March. An important function of the accessory bursa is the storage and breakdown of surplus sperm. Neither of the sperm sacs in Otina appears to be homologous with the receptaculum seminis of the prosobranchs and of Actaeon (Guiart, I90I) which lies near the site of fertilization between the albumen and capsule glands. Here sperm is stored immediately after copulation and becomes oriented on the epithelium, and in some prosobranchs it is later resorbed.

\section{EGGS AND DEVELOPMENT}

Otina breeds at Wembury during the latter half of May and the first fortnight of June. The egg capsules are typically found in crevices, on more or less clean rock surfaces, in company with groups of the ovipositing animals. Each egg mass (Fig. I2 A) forms a small irregular cluster about 4-5 mm across, loosely attached to the substratum. It consists of a single layer of twenty to thirty eggs surrounded by a tough, translucent mucoid secretion, pale yellow or straw coloured. The eggs are ovoid, $0.3 \mathrm{~mm}$ in length, pale yellow in colour. They are surrounded by a layer of albumen, whitish and finely granular, and enclosed in a thin tough capsule, quite smooth and transparent. The egg capsule stains pale blue in azan, as well as black in thionin, identically with the cells of the posterior mucous gland from which it is evidently derived. The investing jelly appears to be the secretion of the anterior mucous gland which is always thick and distended prior to the time of egg laying.

Embryos in eggs were abundant at the end of the first week in June. At liberation (Fig. I2B, C) they are equipped with a wide-throated, trumpetmouthed shell, quite transparent and with only a few fine growths striae for sculpture. The visceral mass, which is yellow from the large amount of yolk, is contained in the large apical bulb, and the distinctive character of the 
in Pulmonata but represents the usual condition in Prosobranchia. On either side, the parietal ganglia are closely drawn into the nerve ring, the pleuroparietal commissure being on the right very short and on the left wholly lacking as such. There remains in Otina a rather long visceral loop, retaining no trace of torsion, and formed, unlike that of the ellobiids, by the parietovisceral commissure of each side, leading back to the single visceral ganglion.

Turning to the digestive system, the simple character of the stomach may to some extent be a consequence of the small size of the animal, as well as an indication of the primitive condition of this organ. The absence of the posterior caecum, receiving the major typhlosole, seems-for instance-to be a feature in which Otina differs from all of the less specialized genera of the Ellobiidae. The lack of a differentiated muscular gizzard is another primitive negative character, which must be possible in Otina only by reason of the fine, well-comminuted nature of the food particles. Adding to the lack of a gastric gizzard the presence of ciliated excurrent grooves from paired digestive diverticula, and of the vestige of an intestinal 'style sac', we may recognize in the otinid stomach a most convincing transitional stage between the condition of the microphagous Prosobranchiata and that of the 'higher' Basommatophora. A 'ballooning-out' of the posterior muscular pocket, and the further strengthening of its cuticular lining, would give to this part of the stomach, in Otina, the gizzard-like appearance which is a feature of the ellobiids and of all the other aquatic pulmonates yet investigated.

The structure of the digestive gland agrees with what is known of other primitive pulmonates and of at least some opisthobranchs. The glandular epithelium undergoes a cycle of ingestion, excretion and fragmentation. At the last stage it would appear that 'fragmentation phagocytes' become abstricted from the digestive cells, to wander into the stomach where they carry out a non-localized absorptive and digestive function. The occurrence of such a digestive gland, with the fragmentation of its absorptive epithelium, seems to be correlated in pulmonates and opisthobranchs with the loss of the extensive gastric sorting area of the prosobranchs. Amoebocytic cells, of the type which primitively wandered into the lumen of the gut from the blood vessels underlying the sorting area, are now replaced by 'phagocytes' originating directly from the digestive epithelium.

The reproductive system, like the stomach, remains at a primitive level in Otina. An archaic feature, which is shared by most of the ellobiids, is the open communication between the male and female regions of the glandular genital tract. Further, there are indications that at a recent time in phylogeny the male and female genital apertures were widely separated, the female aperture near the pallial opening and the (secondary) male aperture far forward on the head, as is still found in the ellobiids and in all tectibranchs. In Otina these two apertures have now moved secondarily close together, both lying beneath the right oral lappet. From the original common genital aperture, giving rise to the definitive female opening, the secondary male 
aperture must first have been carried forward to the head, by the usual shallow extension of the vas deferens, forming an open groove in tectibranchs and a closed tube just beneath the integument in pulmonates. In Otina, apparently uniquely, the female aperture has been carried anteriorly from its pallial position in the same manner, by the prolongation of the vagina as a narrow muscular tube, closely accompanying the vas deferens.

The albumen gland in Otina, like that of the ellobiids, but unlike the same gland in the actaeonids, has lost its primitive pallial position and has entered the haemocoele, where it no longer forms a tubular section of the genital duct traversed by the eggs, but serves as a glandular annexe communicating rather narrowly with the mucous gland in the neighbourhood of the fertilization pouch. In the male portion of the glandular hermaphrodite duct, the prostate has its characteristic pulmonate position, incorporated in the main course of the genital tract, rather than-as in opisthobranchs-forming a glandular diverticulum of the male duct. The absence of a well-developed muscular penial papilla, and the functioning of the preputium as a 'pseudopenis' must probably be regarded as a specialization due to small size.

Most of the earliest pulmonates, as characterized by the ellobiids, retain a heterostrophic embryonic shell, held to be a common inheritance from the ancestral stock of both pulmonates and opisthobranchs (see Morton, I955 b). In Otina a reduced heterostrophy is still to be seen in the shell of the embryo. Such a condition resembles that of Leucophytia and other ellobiids mentioned by Harry (I95I) and the pyramidellids (Fretter \& Graham, I949). In one ellobiid genus, Melampus, a well-developed velum is retained by a freeswimming larva, and in Leucophytia a large vestige of the velum survives in the unhatched embryo. In the embryo of Otina there is no trace of a velum. An operculum however persists in this, and in all ellobiid embryos studied.

A characteristic feature of pulmonates at a basal level of organization is the occurrence of a protandrous sexual succession. Such a phenomenon has already been described in Leucophytia and Carychium. A similar month-bymonth survey of the condition of the gonad in Otina revealed an extremely close similarity to that of Leucophytia. It should again be pointed out that a clear-cut separation of the sexual stages with complete separation of male and female phases is never obtained. From September to December, while sperms are undergoing maturation in the gonad, small oocytes are already prominent in the germinal epithelium, and the female portions of the glandular genital duct are already fully differentiated, though of very small size. The period of female development, between December and June, is marked by the great increase in the relative size of the albumen and mucous glands, and the reduction in size of the prostatic epithelium. The earlier pulmonates thus show two sexual stages in a single season. A question not finally determined is whether Otina is an annual mollusc, or whether a restitution of male germinal epithelium is possible following the deposition of eggs. From the fact that animals of the whole size range were evidently equally abundant at all times 
of the year, it would seem that Otina, like the majority of pulmonates, undergoes at least a biennial life cycle. An opposite example is that of Skeneopsis, a minute prosobranch, investigated by Fretter (1948) and found to have an annual life cycle, with a great falling off in the numbers of adults during winter months.

The limpet habit in the Basommatophora has been independently developed at least four times, and is associated either with resistance to wave attack on the seashore or with life in fast-flowing inland waters. With the acquisition of its 'lung', Otina must have evolved in a way similar to the larger limpet-like marine pulmonates, the Siphonariidae. The latter family has undergone a parallel reversion from the upper shore to a completely intertidal life (see the monograph by Hubendick, and also the recent papers of Yonge (1952) and Borland (1950). We may suppose that at the level of the origin of the first pulmonates the lung was acquired as part of the heritage of a primitive stock of supratidal gastropods. There are many examples, however, of a return to aquatic life, and among the lower Basommatophora, most of the families are characterized by an early retreat to the sea. Perhaps they never reached far beyond the shore, but acquired the lung-as, for example, in the Ellobiidae and the Amphibolidae-as an adaptation to easier aerial respiration in the turbid, oxygen-poor water of estuaries. Such pulmonates stand rather apart from the four families of the higher 'limnic Basommatophora' (the Lymnaeidae, Physidae, Planorbidae and Ancylidae). Their embryos carry opercula, and most of them bear vestiges of a velum. They retain as a mark of primitiveness a heterostrophic apex, and a relatively long visceral loop. The Siphonariidae are known to have arisen very early, according to Zittel (1923) in the Devonian. Probably the other families of primitive Basommatophora spring from an equally ancient stock; and in a reconsidered arrangement of the Pulmonata these marine families, with probably the Latiidae and Chilinidae, might be placed together in a natural assembly of 'Archaeopulmonata'.

\section{ACKNOWLEDGEMENTS}

The present paper forms part of an investigation of the structure and ecology of British marine pulmonates, completed in the Zoology Department, Birkbeck College, University of London. As in previous papers of this series, it is a pleasure to record my indebtedness to Prof. A. Graham, Dr Vera Fretter, and Prof. C. M. Yonge, F.R.S., from whom I have had much kindness and the privilege of frequent and valued advice. The whole of the work involving living material was carried out at the Plymouth Laboratory of the Marine Biological Association, while I was the occupier of one of the University of London tables; and I am most grateful for the kindnesses extended by the Director, Mr F. S. Russell, F.R.S., and the scientific staff at Plymouth, during that time. Finally, I am indebted to the Council of Queen Mary College for a grant in aid of publication. 


\section{REFERENCES}

Bargmann, Helene E., 1930. The morphology of the central nervous system in the Gastropoda Pulmonata. F. Linn. Soc. (Zool.), Vol. 37, pp. I-59.

BORLAND, CONSTANCE, I950. An ecological study of Benhamina obliquata (Sowerby), a basommatophorous pulmonate, in Otago Harbour. Trans. roy. Soc. N.Z., Vol. 78, pp. 385-93.

CARRIKER, M. R., I946. Observations on the functioning of the alimentary system of the snail, Lymnaea stagnalis appressa Say. Biol. Bull., Woods Hole, Vol. 9I, p. 88.

Ellis, A. E., I926. British Snails. Oxford University Press.

ForREST, J. E., I95I. Feeding mechanisms in dorid nudibranchiate Mollusca. Contribution, Section D, Brit. Ass. Adv. Sci., I95I.

FreTtER, VerA, I943. Studies in the functional morphology and embryology of Oncidiella celtica (F. \& H.) and their bearing on its relationships. F. Mar. biol. Ass. U.K., Vol. 25, pp. 685-720.

- I948. The structure and life history of some minute prosobranchs of rock pools: Skeneopsis planorbis (Fabricus), Omalogyra atomus (Phillipi), Rissoella diaphana (Alder) and Rissoella opalina (Jeffreys). F. Mar. biol. Ass. U.K., Vol. 27, pp. 597-632.

Fretter, Vera \& Graham, A., I949. The structure and mode of life of the Pyramidellidae, parasitic opisthobranchs. F. Mar. biol. Ass. U.K., Vol. 28, pp. 493-532.

Graham, A., I949. The molluscan stomach. Trans. roy. Soc. Edinb., Vol. 6I, pp. 737-78.

GuIART, J., I90I. Contribution a l'étude des Gastéropodes opisthobranches et en particulier des Céphalaspides. Mém. Soc. zool. Fr., T. I4, p. 5-219.

HARRY, H. W., I95I. Growth changes in the shell of Pythia scarabaeus (Linné). Proc. Calif. zool. Cl., Vol. 2 (2), I4 pp.

HuBENDICK, B., I945. Phylogenie und Tiergeographie der Siphonariidae. Zur Kentniss der Phylogenie in der Ordnung Basommatophora und der Ursprungs der Pulmonatengruppe. Zool. Bidr. Uppsala, Bd. 24, pp. I-2I6.

Jefrreys, J. G., I869. British Conchology. Vol. 5, 258 pp. London.

MillotT, N., I937. On the morphology of the alimentary canal, process of feeding and physiology of digestion of the nudibranchiate mollusc, forunna tormentosa (Cuvier). Phil. Trans. B, Vol. 228, pp. I73-217.

Morton, J. E., I95I. The ecology and digestive system of the Struthiolariidae. Quart. F. micr. Sci., Vol. 92, pp. I-26.

- I952 a. The role of the crystalline style. Proc. malacol. Soc. Lond., Vol. 29, pp. 85-92.

- I952 b. A preliminary study of the land operculate Murdochia pallidum (Mesogastropoda, Cyclophoridae). Trans. roy. Soc. N.Z., Vol. 80, pp. 69-79.

- 1954. The crevice faunas of the upper intertidal zone at Wembury. F. Mar. biol. Ass. U.K., Vol. 33, pp. 187-224.

- I955a. The functional morphology of the British Ellobiidae (Gastropoda Pulmonata) with special reference to the digestive and reproductive systems. (In the Press.)

- I955b. The evolution of the Ellobiidae, with a discussion on the origin of the Pulmonata. Proc. zool. Soc. Lond. (in the Press).

Pantin, C. F. A., I946. Notes on Microscopical Technique for Zoologists. Cambridge University Press.

Pelseneer, P., I901. Études sur des Gastéropodes Pulmonées. Mém. Acad. R. Belg. Cl. Sci., T. 54, p. I. 
Station Biologique de Roscoff, I95i. Inventaire de la Faune Marine de Roscoff. Molusques. Trav. Sta. biol. Roscoff, Suppl. 5, 80 pp.

ThIELE, J., I93I. Handbuch der Systematischen Weichtierkunde. I-2. Jena.

YONGE, C. M., I926. The structure and physiology of the organs of feeding and digestion in Ostraea edulis. F. Mar. biol. Ass. U.K., Vol. I4, pp. 295-386.

- I939. The protobranchiate Mollusca: a functional interpretation of their structure and evolution. Phil. Trans., B, Vol. 230, pp. 79-I48.

- 1952. The mantle cavity in Siphonaria alternata Say. Proc. malacol. Soc. Lond., Vol. 29, pp. 190-199.

Zittel, K. A. von, I923. Grandzuge der Palaontologie I. Invertebrata. Munich and Berlin. 